\title{
Article 13 (b) vs Immunity of State Officials
}

Rarely is there a subject that attracts more antagonism than the immunity of State officials for crimes such as aggression, genocide, crimes against humanity and war crimes. The debate on whether foreign criminal fora can exercise jurisdiction over individuals that act in the name of a State revolves around the interplay between international criminal law and the international law on immunities. The latter regime, on the one hand, proceeds from the well-established rule that declares the State and its officials immune from the jurisdiction of other States. The former, on the other hand, is predicated on humanitarian values contained inter alia in the Nuremberg and Tokyo judgments, the Convention against Genocide, the Geneva Conventions, the Eichmann Case, the Convention against Torture, the jurisprudence of the ad hoc tribunals, the Pinochet Case, many other national proceedings and the Rome Statute; all of which call for the accountability of perpetrators of international crimes, regardless of their official position. International law seeks to accommodate both of these regimes.

This chapter addresses the immunities under international law of State officials from proceedings before the ICC and from national proceedings enforcing an ICC arrest warrant emanating from a situation referred under Article 13 (b) of the Rome Statute. The immunities of high and low ranking officials will be described in the first section. The first section will also show that there is a measure of indeterminacy as to whether the immunity of high-ranking State officials from States not party to the Rome Statute is relevant before the ICc. Against this background, the next two sections will analyze under the 'Chapter VII conception' and the 'universal jurisdiction conception' whether a State official from a State not party to the Rome Statute is entitled to invoke its immunity before the ICC when the latter exercises jurisdiction under Article 13 (b). Finally, as it is highly improbable that a State official from a State not party to the Statute would appear voluntarily before the ICC, the last part of this analysis will inquire, using both 'conceptions', whether the immunities of State officials are a bar to national authorities enforcing an arrest warrant from the ICC.

The immunities of State officials under international law can be separated into two categories: (1) immunity ratione materiae which any State official enjoys 
when performing official acts; and (2) immunity ratione personae which only holders of high office enjoy for any acts. ${ }^{1}$ The rationale of both immunities ratione materiae and personae is to "ensure the effective performance of their functions on behalf of their respective States." Thus, immunities are not for the benefit of the individual exercising the functions.

Immunity ratione materiae is attached to the functions of the official, while immunity ratione personae relates to the position of the official. Immunity $r a-$ tione materiae does not cover personal acts, but continues to subsist even after the official ceases to perform his or her official functions. It is for this reason that we speak of immunity attached to the acts of the official while performing his or her functions. Hence the qualification that this immunity is based on the principle of equality of States: a State does not judge the acts of another State par in parem imperium non habet. ${ }^{3}$

Immunity ratione personae is a procedural defense based on the notion that any activity of an incumbent Head of State, Head of government, foreign affair minister and diplomatic agent $t^{4}$ must be immune from any interference of a foreign State. It covers official and private acts committed prior to and during office. ${ }^{5}$ It does not exculpate high-ranking State representatives from their responsibility as immunity ratione materiae does but it does grant procedural immunity. Put simply, a high-ranking State representative enjoying immunity ratione personae is liable but foreign domestic courts are barred

1 This distinction was adopted by France and Djibouti in Certain Questions of Mutual Assistance in Criminal Matters (Djibouti vs France), ICJ Reports 2008, at 177; Al-Adsani v. United Kingdom, European Court of Human Rights, Judgment, Application No. 35763/97, 21 November 2001, par. 65; Ferdinand et Imelda Marcos c. Office fédéral de la police (recours de droit administratif), Switzerland, Tribunal fédéral, ATF $115 \mathrm{Ib} 496$, at 501-502; Pinochet (No. 3), at 581 (in particular: Lord Browne-Wilkinson, at 592; Lord Goff of Chieveley, at 598; Lord Hope of Craighead, at 622; Lord Hutton, at 629; Lord Saville of Newdigate, at 641, and Lord Millet, pp. 644-645). However, the International Court of Justice in the Arrest Warrant Case, did not refer to this classification. See Cassese, "When May Senior State Officials Be Tried," 862-864.

2 Arrest Warrant Case, par. 53 .

3 Prosecutor v. Blaskic, Case No. IT-95-14-AR1o8bis, Judgment on the Request of the Republic of Croatia for Review of the Decision of Trial Chamber II of 18 July 1997 (Oct. 29, 1997), par. 41.

4 Nevertheless, diplomatic immunity is confined to the States where the agent is accredited and to the States where he passes while proceeding to or returning from his post; see Vienna Convention on Diplomatic Relations, Art. 40. Conversely, the immunity ratione personae of the other high-ranking State representatives is erga omnes.

5 Gadaffi, Arrêt No. 1414 of 13 March 2001, reprinted in: 105 Revue Générale de Droit International Public (2001) 474 . 
from exercising jurisdiction. However, immunity ratione personae can only be enjoyed by incumbent Heads of States and other high-ranking State representatives; ${ }^{6}$ when they cease to hold office immunity ratione personae also ceases but immunity ratione materiae remains. ${ }^{7}$

Any discussion relating to immunities of State officials and international crimes must refer to the ICJ judgment on the Case Concerning the Arrest Warrant of 11 April 2000 (Democratic Republic of the Congo v. Belgium) (hereinafter Arrest Warrant Case). In this case, the ICJ, after reviewing national and international case law and instruments, declared that customary international law does not provide any exception to the immunity of a foreign affairs minister before foreign criminal jurisdiction even where suspected of war crimes and crimes against humanity. ${ }^{8}$ Nonetheless, the ICJ then stressed that "immunity from jurisdiction enjoyed by incumbent Ministers for Foreign Affairs does not mean that they enjoy impunity". ${ }^{9}$ In order to exemplify this statement, the ICJ enumerated four circumstances where the immunity of a sitting high-ranking State representative would not represent a bar to criminal prosecution: (1) when the national authorities of the State they represent institute proceedings; (2) when the State they represent waives the immunity; (3) when the high-ranking State representative does not hold office anymore, other States "may try the former high-ranking officials in respect of acts committed prior or subsequent to his or her period of office, as well as in respect of acts committed during that period of office in a private capacity"; ${ }^{10}$ and, (4) when the high-ranking State representative is subject to proceedings before "certain international criminal courts, where they have jurisdiction."11

The first and second circumstances, i.e. national proceedings and waiver of immunity, have not created significant disagreement. They rest upon fundamental principles of international law: sovereignty and consent. In this sense they confirm principles that were well established in international law and that arguably did not need any clarification. However, the third and the fourth circumstances, namely prosecution of former officials for acts committed in a

6 See ILC, Second Report of the Special Rapporteur, Ms. Concepción Escobar Hernández (Apr. 4, 2013) U.N. Doc. A/CN.4/661, provisionally adopted at the 65th session of the International Law Commission.

7 Cassese, "When May Senior State Officials Be Tried," 864-865.

8 Arrest Warrant Case, par. 58.

$9 \quad$ Ibid., par. 6o.

$10 \quad$ Ibid., par. 61.

11 Ibid., par. 61. 
private capacity and prosecution before "certain international criminal courts, where they have jurisdiction" have been the subject of a hot debate between scholars and of varying interpretation by international courts.

The third circumstance applies when the high-ranking State official no longer holds office - he then enjoys immunity ratione materiae; other States "may try the former high-ranking officials in respect of acts committed prior or subsequent to his or her period of office, as well as in respect of acts committed during that period of office in a private capacity". ${ }^{2}$ In other words, the former high-ranking official is still immune from foreign criminal jurisdiction for the acts committed in an official capacity. Obviously, this is difficult to reconcile with the principle of individual criminal responsibility for international crimes committed in the name of the State. ${ }^{13}$ As Judge Van den Wyngaert ${ }^{14}$ and many commentators have argued, ${ }^{15}$ most international crimes are committed on behalf of the State, and to negate the official character of such crimes would "be to fly in the face of reality."16 Furthermore, if the authorities of the home State remain in connivance with the former State official, it is highly unlikely that national proceeding will be instituted against the former official (first circumstance) or that a waiver of immunity from foreign criminal jurisdiction will be issued (second circumstance). Consequently, impunity is almost ensured. While Judges Higgins, Kooijmans and Buergenthal in their separate opinion underline that international crimes cannot be regarded as official acts, the silence of the majority judgment on this point leaves the issue unsettled and at risk of being interpreted to the contrary. ${ }^{17}$ Cassese, and many others, claimed that the ICJ neglected to recognize that there is a specific exception under customary international law to immunity ratione materiae for international crimes. ${ }^{18}$ It seems indeed that the third circumstance brings more confusion than clarification.

\footnotetext{
12 Ibid., par. 61 (emphasis added).

13 Nuremberg Principle No. I.

14 Arrest Warrant Case, Separate opinion of Judge ad hoc Van den Wyngaert, par. 34-36.

15 See e.g. Cassese, "When May Senior State Officials Be Tried,"; Koller, "Immunities of Foreign Ministers," 7; Sassòli, "L’arrêt Yerodia," 791; Wouters, "Critical Remarks," 253-267.

16 Barker, International Law and International Relations, 153.

17 Arrest Warrant Case, Joint separate opinion of Judges Higgins, Kooijmans and Buergenthal, par. 85 .

18 Cassese, "When May Senior State Officials Be Tried," 864-866, 870-874; Institut de Droit International, Resolution on Immunities from Jurisdiction and Execution of Heads of State and of Government in International Law, adopted by the Institut at its Vancouver session in 2001, at 742-755.; Gaeta, "Official Capacity," 979-982; Zappala, "Heads of State in Office," 601-6o2; Akande, "International Law Immunities," 414; Prosecutor v. Karadzic et al., Case No. IT-95-5-D, Decision on the Bosnian Serb Leadership Deferral Proposal
} 
The significance of the words used in the Arrest Warrant Case's obiter dictum to delineate the fourth circumstance merit its quotation in full:

an incumbent or former Minister for Foreign Affairs may be subject to criminal proceedings before certain international criminal courts, where they have jurisdiction. Examples include the International Criminal Tribunal for the former Yugoslavia, and the International Criminal Tribunal for Rwanda, established pursuant to Security Council resolutions under Chapter VII of the United Nations Charter, and the future International Criminal Court created by the 1998 Rome Convention. The [Rome] Statute expressly provides, in Article 27, paragraph 2, that "[i]mmunities or special procedural rules which may attach to the official capacity of a person, whether under national or international law, shall not bar the Court from exercising its jurisdiction over such a person." 19

Was the ICJ, in the present case, providing a general exception to the immunity of State officials for proceedings before international criminal courts? Or can this exception be qualified?

From the outset, it is worth emphasizing that not every international criminal court can exercise jurisdiction over an official entitled to immunity but only "certain international criminal courts". Instead of detailing the conditions and criteria required to qualify as one of "certain international criminal courts", the ICJ offered examples of tribunals and courts it considered to be within what one might call a privileged category. According to the ICJ, the ICTY and the ICTR, established pursuant to SC resolutions adopted under Chapter VII of the UN Charter, and the ICC, created by the Rome Statute, may submit to criminal proceedings officials entitled to immunity ratione materiae and ratione personae. Yet, the Court provided no guidance as to what makes these courts more entitled to overrule immunities of State officials than other international criminal courts. For instance, can the Special Tribunal for Lebanon, ${ }^{20}$ established pursuant to a SC resolution adopted under Chapter vII, or the Lockerbie

(May 16, 1995), par. 22-24; Prosecutor v. Furundzija, Case No. IT-95-17/1 (Dec. 10, 1998), par. 140; Prosecutor v. Milosevic, Case No. IT-02-54, Decision on Preliminary Motions (Nov. 8, 2001), par. 28; Prosecutor v. Blaskic, Case No. IT-95-14-AR1o8bis, Judgment on the Request of the Republic of Croatia for Review of the Decision of Trial Chamber II of 18 July 1997 (Oct. 29, 1997), par. 41.

19 Arrest Warrant Case, par. 61 (emphasis added).

20 SC Res. 1757 (2007) of 30 May 2007, UN Doc. S/RES/1757, authorizing the establishment of special tribunal to try suspects in assassination of Rafiq Hariri. 
Court, ${ }^{21}$ created by a treaty, submit any State officials to criminal proceedings? Furthermore, according to the ICJ it is not enough to fit within the category of "certain international criminal courts". Indeed, it is also required to "have jurisdiction". Does this mean that even if the ICC is part of these "certain international criminal courts", there are still some cases where it would lack jurisdiction over certain State officials? Or, is this additional criterion pleonastic?

The ICJ cited Article 27(2) of the Rome Statute to evidence the prototype of a provision that bestows jurisdiction over any State official, irrespective of their immunity. ${ }^{22}$ Article $27(2)$ of the Rome Statute explicitly rejects immunity ratione personae; however this explicit provision is new in international criminal law instruments. ${ }^{23}$ Conversely, the earlier provisions of the ad hoc tribunals rejected immunity ratione materiae but not immunity ratione personae (at least not explicitly). ${ }^{24}$

Furthermore, none of the prior international criminal courts was able to try an official entitled to immunity ratione personae at the time of the proceedings. The first serving Head of State to appear before an international criminal court was Uhuru Kenyatta and this only happened in $2014 .{ }^{25}$ Before this groundbreaking case all trials involving high-ranking State officials occurred when the official ceased to hold office, i.e. when they could only possibly invoke their immunity ratione materiae. ${ }^{26}$ The provisions as well as the precedents of other international criminal courts and tribunals were essentially focused on establishing that officials bore criminal responsibility for crimes that

21 Agreement between the Government of the United Kingdom of Great Britain and Northern Ireland and the Government of the Netherlands concerning a Scottish Trial in the Netherlands (Sept. 18, 1998) 2062 I-35699 UNTS 82.

22 Rome Statute, Art. 27 reads as follows: "1. This Statute shall apply equally to all persons without any distinction based on official capacity. In particular, official capacity as a Head of State or Government, a member of a Government or parliament, an elected representative or a government official shall in no case exempt a person from criminal responsibility under this Statute, nor shall it, in and of itself, constitute a ground for reduction of sentence. 2. Immunities or special procedural rules which may attach to the official capacity of a person, whether under national or international law, shall not bar the Court from exercising its jurisdiction over such a person."

23 Schabas, Commentary on the Rome Statute, 446.

24 The provisions of the ad hoc tribunals are substantially reflecting Article 7 of the London Charter and the resulting Nuremberg Principle No. 3 which states that " $[\mathrm{t}]$ he fact that a person who committed an act which constitutes a crime under international law acted as Head of State or responsible Government official does not relieve him from responsibility under international law." See Schabas, Commentary on the Rome Statute, 450-452; See Bassiouni, "Jus Cogens and Obligatio Erga Omnes," 85.

25 ввс News, Kenyatta Appears at ICC in Hague for Landmark Hearing, 8 October 2014.

26 See sections 3,4 of this chapter. 
were within these tribunals' jurisdiction, but not at securing the criminal jurisdiction of the tribunals over officials enjoying immunity ratione personae. ${ }^{27}$

The principle that an official position cannot relieve the accused of their criminal responsibility for international crimes is contained in Article 27(1), not in Article $27(2)$ of the Rome Statute. ${ }^{28}$ Article 27 (1) ensures that criminal responsibility can be found without any distinction based on official capacity and Article 27 (2) ensures that the Court has jurisdiction over officials normally entitled to procedural immunity from criminal jurisdiction. ${ }^{29}$ However, as the ICJ noted "immunity from criminal jurisdiction and individual criminal responsibility are quite separate concepts." Indeed, the difference between these two separate concepts is encapsulated in Article 27 of the Rome Statute. ${ }^{30} \mathrm{Nev}$ ertheless, this dichotomy is a novelty of the Rome Statute.

Allegedly, the Rome Statute as a treaty can only bind its States parties unless it embodies a norm of customary international law. While Article 7 of the London Charter, Article 6 of the Charter of the Tokyo Tribunal, Article 7 (2) of the ICTY Statute, Article 6 (2) of the ICTR Statute and Article 27(1) of the Rome Statute reflect customary international law, ${ }^{31}$ the same cannot be so easily said about Article 27(2) of the Rome Statute. ${ }^{32}$ In other words, Article 27 (2) is possibly only a conventional exception to the general rule on immunity ratione personae. ${ }^{33}$ This would entail that customary international law provides an exception for proceedings before certain international criminal courts only with regard to immunity ratione materiae ${ }^{34}$ immunity ratione personae would remain applicable, unless the State of the official is deemed to have waived the immunity. Others instead argue Article 7 of the London Charter, Article 6 of the Tokyo Charter, Article 7 (2) of the ICTY Statute, Article 6 (2) of the ICT R Statute

27 Bassiouni, International Criminal Law, 75, 82; Kress, "Immunities under International Law," 252; Baban, La responsabilité pénale du chef d'Etat, 349.

28 See Van Alebeek, The Immunity of States and Their Officials, 265-275; Baban, La responsabilité pénale du chef d'Etat, 349.

29 Broomhall, International Justice, 138; Van Alebeek, The Immunity of States and Their Offcials, $265^{-275}$.

30 See Schabas, The UN International Criminal Tribunals, 328.

31 They all substantially reflect the Nuremberg Principle No. 3 which has been adopted by the United Nations and reiterated by the Secretary General in its report on the Statute of the ICTY has being a norm that all States that issued written comments on the Statute agreed that there should be such a provision, Report of the Secretary-General pursuant to paragraph 2 of Security Council resolution 808 (1993), UN Doc. S/25704 (May 3, 1993). See Kress, "Immunities under International Law," 250-256, Van Alebeek, The Immunity of States and Their Officials, 265-275; Aurey, "Article 27," 843-862.

33 Aurey, "Article 27," 843-862; Kiyani, "Al-Bashir \& the ICC,".

34 See section 4 of this chapter re foreign domestic jurisdiction. 
and Article 27(1) of the Rome Statute are capable of removing immunity ratione materiae as well as ratione personae. ${ }^{35}$ According to Pedretti, for instance, Article 27(2), can "be regarded as a precautionary measure ensuring that the invalidation of the plea of immunity before the ICC is beyond doubt". ${ }^{36}$ In the next sections we will see there are strong and soft versions of the 'Chapter VII conception' and 'universal jurisdiction conception' on how to interpret Article $27(2)$, and how it applies to non-party States. Remove Immunities before International Criminal Courts

The 'Chapter VII conception' proceeds on the assumption that Article 27(2) of the Rome Statute is only a conventional exception to the general rule on immunity ratione personae. Indeed, immunity ratione personae becomes irrelevant if the State of the official is deemed to have waived it. ${ }^{37}$ Likewise, it can be argued that State parties to the Rome Statute have consented that the immunity their officials, including high-ranking officials, would normally enjoy from the ICc's jurisdiction is inapplicable.

According to a strict positivistic view, international criminal courts' rights to exercise jurisdiction over an official entitled to immunity ratione personae is grounded on the same rationale as national courts. As seen above, the ICJ stated in the Arrest Warrant Case that a foreign national court may exercise jurisdiction over the State official of another State if the latter waives its immunity. ${ }^{38}$ In such cases jurisdiction can be exercised because the State's right to immunity has been relinquished. The same applies mutatis mutandis when a State is considered to have relinquished its right to immunity towards an international criminal court. ${ }^{39}$

If customary international law does not provide an exception to immunity ratione personae for proceedings before international criminal courts, such an exception has to be found in the legal basis of the court. ${ }^{40}$ The legal basis of a

35 Pedretti, Immunity, 246; Akande, "International Law Immunities," 420.

36 Pedretti, Immunity,. 246; Akande, "International Law Immunities," 420; see also ILC, Draft Code of Crimes against the Peace and Security of Mankind, with commentaries, (1996), at 27 .

37 Arrest Warrant Case, par. 61.

38 Ibid., par. 61.

39 Morris, "High Crimes," 485; arguing that Article 27 is only a waiver of immunity for States parties.

40 Van Alebeek, The Immunity of States and Their Officials, 265-295. 
court to exercise jurisdiction over a high-ranking official will determine whether the State from which the individual derives their immunity is bound to accept the court's jurisdiction. In this respect, there is a significant difference between international criminal courts established pursuant to SC resolutions adopted under Chapter viI of the UN Charter and courts created by a treaty. ${ }^{41}$ Upon joining an international organization a State consents to the constituent instrument and to the institutional aspects of the organization. ${ }^{42}$ If the constituent instrument provides that immunities are not applicable before this international organization -like the Rome Statute does through Article 27(2) members of this organization are to be considered as having lifted the right to immunity they had under international law. ${ }^{43}$

In Prosecutor v. Uhuru Kenyatta, the first case where an incumbent Head of State appeared before an international criminal court, the ICC never addressed the immunity of the defendant. ${ }^{44}$ It is true that, on the one hand, the Court considered that, in exceptional circumstances, a Chamber may exercise its discretion to excuse an accused on a case-by-case basis in order to enable him to perform his functions of State from continuous presence at trial. ${ }^{45}$ Immunity, on the other hand, was never raised. ${ }^{46}$ That can be simply explained by the fact that by ratifying the Rome Statute, including Article 27 (2), Kenya, of which Kenyatta was the Head of State, is considered to have waived this right it was entitled to under international law. Accordingly, the legal basis of the court to exercise jurisdiction over a situation provides the answer as to whether a

41 Koller, "Immunities of Foreign Ministers,"; Tunks, "Diplomats or Defendants?," 654; Van Alebeek, The Immunity of States and Their Officials, 265-295.

42 Brownlie, Principles, 292.

43 VCLT, Art. 26.

44 Prosecutor v. Muthaura and Kenyatta, Case No. ICC-o1/og-02/11-382-Red, Decision on the Confirmation of Charges Pursuant to Article 61(7)(a) and (b) of the Rome Statute, (Jan. 23, 2012); Prosecutor v. Kenyatta, ICC-o1/og-02/11, Decision on Defence request for excusal from attendance at, or for adjournment of, the status conference scheduled for 8 October 2014 (Sept. 30, 2014).

45 Prosecutor v. Kenyatta, Case No. ICC-o1/o9-02/11-83o, Decision on Defence Request for Conditional Excusal from Continuous Presence at Trial (Oct. 18, 2013). However, the Appeals Chamber found that the Trial Chamber had not properly exercised its discretion, as it had granted the accused a 'blanket excusal before the trial had even commenced, effectively making his absence the general rule and his presence an exception', Prosecutor v Ruto and Sang, Case No. ICC-o1/og-o1/11-1066, Judgment on the appeal of the Prosecutor against the decision of Trial Chamber V(a) of 18 June 2013 entitled 'Decision on Mr. Ruto's Request for Excusal from Continuous Presence at Trial' (Oct. 25, 2013).

46 However, see Prosecutor v Ruto and Sang, Case No. ICC-o1/o9-01/11-777, Decision on Mr Ruto's request for excusal from continuous presence at trial (Jun. 18, 2013), par. 64-71. 
particular State has removed the immunity of its officials in respect of the proceedings in question.

The ICJ did provide for an exception to the rule on immunity for "certain international criminal courts, where they have jurisdiction". Thus, prima facie, we seem to be in a rule 'rule-exception' relationship. However, when drafting the constituent instrument of an organization, States cannot create obligations for States that do not consent to it. The pacta tertiis rule is the most important objection to a treaty-based court's exercise of jurisdiction over officials of a State not party to the treaty establishing the said court. ${ }^{47}$ States while ratifying the statute of a treaty-based court are only entitled to waive their own right to immunity not the rights of others. ${ }^{48}$ Accordingly, international criminal courts are limited to exercising jurisdiction over high-ranking State officials from States that consented to the constituent instrument of the court.

The 'Chapter VII conception' does not consider that in every situation where the ICC exercises jurisdiction the immunity of State officials is not a bar to prosecution. Quite the contrary, it views the immunity of high-ranking officials from non-party States as a bar to the Court's jurisdiction, unless immunity has been removed by the concerned State. Such a removal can be obtained (1) through ratification of the Rome Statute by the concerned State; (2) issuance of an ad hoc declaration under Article 12(3) by the concerned States;(3) issuance of an ad hoc waiver by the concerned State, or (4) implied waiver/ removal residing on the Chapter viI obligation to accept the SC decision to refer a situation to the ICC, and the obligation of the concerned State to "cooperate fully with the Court" potentially emanating from a SC resolution to that effect. While the three first examples of a waiver are explicit, the last is implied. Interpretation is thus needed. What is required for a simple accumulation of norms is that no room be left for interpretation. Hence, an apparent conflict arises when a high-ranking official of a non-party State, which has not issued a waiver of immunity, is prosecuted by the ICc.

The Court has considered that this apparent conflict can be avoided in two different ways. First, through the tool of effective interpretation (effet utile) we can imply that SC referrals to the ICC, with an obligation to cooperate fully with the Court, entail that the immunity of the targeted State is waived by the SC. This is the view the ICC Pre-Trial Chamber II adopted in the Decision on DRC Failure to Arrest Al-Bashir. According to the Chamber, Al-Bashir, the head

47 See Morris, "High Crimes," 485; Akande, "International Law Immunities," 419-20; Wirth, "Immunity for Core Crimes," 888; Tunks, "Diplomats or Defendants?," 665 fn 75; Cryer et al., International Criminal Law and Procedure, 551. 
of State of Sudan, a non-party State, did not enjoy immunity under international law, because that immunity had been implicitly waived by the Security Council, which had also imposed on the Sudan a general obligation to cooperate with the Court, when it referred the situation in Darfur to the ICC. ${ }^{49}$

Second, again through the tool of effective interpretation, a Security Council referral, supplemented with an obligation to cooperate with the Court, clearly entail that the legal framework of the Rome Statute, including Article 27 (2), applies to the situation referred. Given that the ICC can only exercise jurisdiction in accordance with the provisions of its Statute, when the SC refers a situation to the ICC it makes the Court's legal regime applicable to the referred State, even if the latter is not a party to the Rome Statute. Hence, the immunities of the referred State are not waived, they are simply made irrelevant, as the wording of Article 27 indicates. This is the view the ICc Pre-Trial Chamber II took in Decision on South Africa Failure to Arrest Al-Bashir. In this case, the Chamber found "that, for the limited purpose of the situation in Darfur, Sudan has rights and duties analogous to those of States Parties to the Statute.".50

Both interpretation start with the assumption that if the constituent instrument of an international organization provides that an organ of the international organization can issue decisions that are binding upon each member such as the UN Charter regarding the SC powers - each member has to perform its obligations in good faith and accept and carry out the decisions of the organ. The constituent instrument is, indeed, what regulates the obligations of States and of the international organization itself. Both interpretation can also find support in the ICJ advisory opinion on Legal Consequences for States of the Continental Presence of South Africa in Namibia. ${ }^{51}$ In this decision concerned with SC Resolution 276 that declared South Africa's presence in Namibia illegal, without requiring other UN Member States to do anything, the ICJ found that all States were under the obligation to recognize the illegality of South Arica's presence and to refrain from any acts that would imply the recognition

49 Prosecutor v. Al-Bashir, Case No. ICC-02/05-01/og, Decision on the cooperation of the Democratic Republic of the Congo regarding Omar Al Bashir's arrest and surrender to the Court (Apr. 9, 2014), par. 29 (hereinafter Decision on DRC Failure to Arrest Al-Bashir).

50 Prosecutor v Al-Bashir, Case No. ICC-02/05-01/o9, Decision under article 87(7) of the Rome Statute on the non-compliance by South Africa with the request by the Court for the arrest and surrender of Omar Al-Bashir (Jul. 6, 2017), par. 88 (hereinafter Decision on South Africa Failure to Arrest Al-Bashir).

51 Legal Consequences for States of the Continental Presence of South Africa in Namibia (SouthWest Africa) Notwithstanding Security Council Resolution 276 (1970), Advisory Opinion, 1971 ICJ REP. 16 (June 21); Akande, "Impact on Al-Bashir's Immunities," 347; De Wet, "The Implications of President Al-Bashir," 1062. 
of the legality of South Africa's occupation. ${ }^{52}$ If such purposive effects were not given to the SC resolution, "it would deprive this principal organ of its essential functions and powers under the UN Charter."53 Both, the Decision on DRC Failure to Arrest Al-Bashir and Decision on South Africa Failure to Arrest Al-Bashir certainly rely on a similar purposive interpretation of the $S C$ referrals.

One of the distinction between the two interpretations is however that one relies on the intention of the SC to waive immunities, while the other emphasizes that when referring a situation to the Court, the SC accepts that the Court will apply its legal regime to a State that has not ratified the Statute. The latter approach avoids the contention that if the SC intended to waive the immunity of high-ranking State officials, it should have been explicit.

Let us take the examples of the ad hoc tribunals to show how effective interpretation of SC resolutions removes immunities. The ICTY and the ICTR were created by resolutions of the SC adopted under Chapter viI of the UN Charter. When the ad hoc tribunals exercised jurisdiction, their legal bases were the SC resolutions creating them, so the Chapter VII powers. ${ }^{54}$ Due to their obligations under the UN Charter, UN Member States had to accept and carry out the ad hoc tribunals' exercise of jurisdiction. ${ }^{55}$ In spite of the customary rule that immunities are a bar to a foreign court's exercise of jurisdiction, UN Member States had consented via the Charter to the SC's decision to make immunities irrelevant to the ad hoc tribunals' exercise of jurisdiction. ${ }^{56}$

Similarly, under the 'Chapter viI conception' of a referral under Article 13 (b), the legal basis of the ICC over a Head of State is the SC resolution referring the situation to the ICC. Due to their obligations under the UN Charter, UN

$5^{2}$ Legal Consequences for States of the Continental Presence of South Africa in Namibia (SouthWest Africa) Notwithstanding Security Council Resolution 276 (1970), Advisory Opinion, 1971 ICJ Rep 16 (June 21), par. 114-116, 119.

53 Ibid., par. 116.

54 The constituent instruments of the IСтY and the IстR have legal effect over all UN Member States; Akande, "International Law Immunities," 417; Cryer et al., International Criminal Law and Procedure, $55^{2-553 .}$

55 Under Art. 25 and 48 of the UN Charter, members must accept and carry out decisions of the SC taken under Chapter vII. See Case concerning Questions of Interpretation and Application of the 1971 Montreal Convention arising from the Aerial Incident at Lockerbie (Libyan Arab Jamahiriya v. the United Kingdom) (Provisional Measures) 1992 ICJ Reports 15, par. 39; It may be asked whether the SC can remove the rights of immunity of UN third States parties; see Koller, "Immunities of Foreign Ministers," 33-34; see also Akande, "Nationals of Non-Parties," 628-631; Doria, "Conflicting Interpretations," 278-279 (argues that the SC decisions taken under Chapter VII are also binding States not party to the UN because of Article 2(6) of the UN Charter) 
Member States have to accept and carry out the decision of the SC taken under Chapter VII to grant jurisdiction to the ICC over a certain situation. ${ }^{57}$ Even if immunities are generally a bar to ICC's exercise of jurisdiction over the highranking official of a non-party State, in a situation triggered by the SC all States have to accept the ICC's exercise of jurisdiction in accordance with its Statute, including Article 27.58 The ad hoc tribunals jurisdiction is indeed suggesting that the correct way to interpret how immunities are made inapplicable before the ICC is to a certain extent to be found in Decision on South Africa Failure to Arrest Al-Bashir.

This reading however suggests that in a situation triggered by the SC the immunities of high-ranking officials from all States, irrespective of whether they are non-party States, are irrelevant for prosecution before the ICC. Article 48 specifies that the SC may determine whether the actions required to carry out its decisions shall be taken by all the UN Member States or only by some of them. Both SC resolutions creating the ad hoc tribunals explicitly obliged all States to cooperate fully with the ad hoc tribunals. ${ }^{59}$ Yet, the SC could have decided to establish the ad hoc tribunals without specifying that States were to cooperate and consequently take measures domestically to implement the resolutions and the orders of the tribunals. UN Member States would have therefore been under no obligation to cooperate with the tribunals but still they would have had to accept the ad hoc tribunals' exercise of adjudicative jurisdiction. ${ }^{60}$ Accordingly, the removal of immunities would have been operated by the obligation, pursuant to Article $25 \mathrm{UN}$ Charter, to accept and carry out the ad hoc tribunals exercise of jurisdiction, and the Statutes establishing them. ${ }^{61}$ In this regard, it must be noted that many hold that the provisions of the ad hoc tribunals on immunities, which closely resemble Article 27(1), had the capacity to remove immunity ratione personae as well. ${ }^{62}$

The practice of the SC in referrals to the ICC demonstrates that the explicit obligation to cooperate are generally restricted to the territorial State. ${ }^{63}$

57 UN Charter, Art. 25 .

58 Akande, "International Law Immunities," 417.

59 The SC resolutions creating the ad hoc tribunals explicitly obliged every UN Member State to undertake any measures necessary under their domestic law to implement the provisions of the Statutes and to enforce any order to arrest and surrender an accused to the Tribunals. SC Res. 827 (1993), op. par. 4; SC Res 955 (1994), op. par. 2.

6 Decision on Taylor Immunity, par. 38, 57 .

61 Akande, "International Law Immunities," 417.

62 Pedretti, Immunity, 246; Akande, "International Law Immunities," 42o; Decision on Taylor Immunity, par. 53; ILC, Draft Code of Crimes against the Peace and Security of Mankind, with commentaries, (1996), at 27.

63 SC Res. 1593, par. 1, 2; SC Res. 1970, par. 5, 6. 
Indeed, the referrals of Darfur, Sudan and Libya oblige only these two targeted States "to cooperate fully" with the Court. However, all other UN Member States have to accept the SC decision to refer the situations in Darfur and Libya to the ICC, a judicial institution that in the first place considers immunities irrelevant before its jurisdiction. Thus, if a crime takes place within the territory of Darfur or Libya and is sufficiently linked to the situations referred by the SC, no State official from a UN Member State is immune from the Court's jurisdiction. ${ }^{64} \mathrm{But}$, except for the States under an obligation to cooperate stemming from either the Rome Statute or the respective SC resolution, States are not obliged to cooperate with the Court. The latter aspect will be particularly important with respect to immunity from arrest and surrender to the Court, as we will see below.

When interpreted in such way, the ICC's exercise of jurisdiction over highranking officials in a situation referred by the SC to the ICC does not genuinely conflict with the immunities of officials of non-party States. The apparent conflict can be interpreted away by recognizing that the SC removed certain international law immunities by subjecting the referred situation to the Rome Statute. A softer version is to hold that the referrals of Darfur, Sudan and Libya oblige only these two States. ${ }^{65}$ If the high-ranking official prosecuted is not acting on behalf of the State targeted by the referral or on behalf of a State party to the Rome Statute, the Court may find that Article 27 (2) is not applicable in its case. ${ }^{66}$

The softer version fails however to make two significant distinction underlying the nature of a SC referral. First, it is not a State that is referred to the ICC but a a situation, albeit territorially linked. ${ }^{67}$ Second, there are different obligations (and different addresses) arising from a SC's conferral of jurisdiction to an institution which has a set of rules designed to govern its jurisdiction, and the obligation of State(s) to cooperate fully with such institution. Indeed, the strong version better reflects the wording and context of the SC resolutions in question, which referred, first, a situation to the Court, and then provided that only certain States have to cooperate with the Court.

To sum up, under current international law, the SC referrals to the ICC override the customary immunity of high-ranking State officials from the Court's

\footnotetext{
64 O'Keefe, International Criminal Law, 109.

65 With regards to the exemptions for nationals of non-party States contained in both referrals, see Chapter 5 , section $2-3$.

66 Rome Statute, Art. 21(1)(b) calls on the Court to apply customary international law, where appropriate.

67 See Chapter 2, section 2.2.3 and Chapter 5, section 2.
} 
jurisdiction. An assessment of the Chapter viI powers underlying the SC referrals and its purposive effects reveal that the conflict between the ICC's exercise of jurisdiction over high-ranking officials from States not party to the Rome Statute can be interpreted away. Statute Provision on Immunity Applies to All

The 'universal jurisdiction conception' proceeds on the basis that Article 27(2) of the Rome Statute is declaratory of a rule of customary international law. Such assumption relies on the fact that the ICJ in the Arrest Warrant Case stated that "an incumbent or former Minister for Foreign Affairs may be subject to criminal proceedings before certain international criminal courts, where they have jurisdiction." The ICC and Article 27(2) Rome Statute were cited by the 'World Court' as examples of this specific exception to the general rule on immunity. Drawing upon the examples of Nuremberg, Tokyo, ICTY, ICTR and the SCSL it is argued that customary international law provides that the immunity of State officials cannot be invoked to oppose a prosecution before a court of an international nature, such as the ICc.

This however does not represent the strongest version of the 'universal jurisdiction conception'. In its 2008 Decision on the Arrest Warrant against Al-Bashir the Chamber considered that the position of Al-Bashir - the head of Sudan, a State not party to the Rome Statute - has no effect on the Court's jurisdiction over the case. The first reason upheld by the Court for dismissing the relevance of Al-Bashir's immunity was that "according to the Preamble of the Statute, one of the core goals of the Statute is to put an end to impunity for the perpetrators of the most serious crimes of concern to the international community as a whole, which 'must not go unpunished." ${ }^{8}$ The second reason offered was that Article 27 made clear that immunities are irrelevant before the Icc. ${ }^{69}$ The third reason was that other sources of law can only be resorted to if there is a lacuna in the Rome Statute, the Elements of Crimes and the Rules. ${ }^{70}$ Thus pointing out that customary international law, especially the international law on immunity, was of no relevance given that Article 27 settled the issue. ${ }^{71}$ Finally, the Chamber specified that by

\footnotetext{
68 Decision to Issue an Arrest Warrant against Al-Bashir, par. 42.

69 Ibid., par. 43.

$70 \quad$ Ibid., par. 44.

71 Gaeta, "Al Bashir Enjoy Immunity," 323.
} 
referring the situation in Darfur to the ICC, the SC had accepted that "the investigation into the said situation, as well as any prosecution arising therefrom, will take place in accordance with the statutory framework provided for in the Statute, the Elements of Crimes and the Rules as a whole".72 Indeed, the PTC's reasoning to dismiss the immunity of Al-Bashir was predominantly relying on the text of the Rome Statute, which apparently bound all heads of States of the international community. The fact that Article 27 is enshrined in a treaty, which according to the basics of the law of treaties does not create obligations for non-party States did not even arise. ${ }^{73}$ It has been shown in Chapter 2 that this position constitutes an exercise of exorbitant treaty-based universal jurisdiction which cannot find a solid legal grounding in contemporary international law.

On the other hand, if Article 27 (2) codifies customary international law, it constitutes an explicit exception to the rule on immunity. In this relationship of "rule-exception" there is simply an accumulation of norms. ${ }^{74}$ The customary rule on immunity is carved out by the customary exception for international courts to the extent required to give it effect but both norms continue to apply in their respective scope of application.

This position was adopted in the ICC Pre-Trial Chamber Decision on Malawi Failure to Arrest Al-Bashir. ${ }^{75}$ In this decision, the Pre-Trial Chamber declared that "the principle in international law is that immunity of either former or sitting Heads of State cannot be invoked to oppose a prosecution by an international court." ${ }^{16}$ The Pre-Trial Chamber stated that its reasoning applies to non-party States whenever the Court may exercise jurisdiction. ${ }^{77}$ In contrast with the Decision on DRC Failure to Arrest Al-Bashir, the Court's jurisdiction

72 Decision to Issue an Arrest Warrant against Al-Bashir, par. 45 .

73 vCLT, Art. 34.

74 Pauwelyn, Conflict of Norms, 162 (if the two norms accumulate, they do not conflict. One form of accumulation that is particularly relevant for us, here, is when "one norm [...] sets out a general rule and another norm [...] explicitly provides for an exception to that rule". In such a case there is no conflict, but accumulation).

75 See also Prosecutor v. Al-Bashir, Case No. ICC-02/05-01/o9, Decision pursuant to article $87(7)$ of the Rome Statute on the refusal of the Republic of Chad to comply with the cooperation requests issued by the Court with respect to the arrest and surrender of Omar Hassan Ahmad Al Bashir (Dec. 13, 2011).

76 Prosecutor v. Al-Bashir, Corrigendum to the Decision Pursuant to Article 87(7) of the Rome Statute on the Failure by the Republic of Malawi to Comply with the Cooperation Requests Issued by the Court with Respect to the Arrest and Surrender of Omar Hassan Ahmad Al Bashir, ICC-o2/05-01/o9-139-Corr (Dec. 15, 2011), par. 36 (hereinafter Decision on Malawi Failure to Arrest Al-Bashir).

Ibid., par. 36 . 
over Al-Bashir did not arise from a waiver (deriving from the SC referral) but from the exceptional customary right of "certain international criminal courts" to declare immunities irrelevant. ${ }^{78}$

Why would there be a specific exception for "certain international criminal courts"? As a matter of principle, the exception to immunity ratione personae for proceedings before international courts could simply reside in a court's legal status. To put it simply, it is the legal status of the court as an organ of the international community that would allow it to overrule the immunity of State officials. According to this line of reasoning, the international nature of a certain criminal court is sufficient per se to make the plea of immunity ratione personae unavailable. ${ }^{79}$ The court's international nature would ensure that the exercise of jurisdiction does not clash with the principles underlying the immunity of State officials. Given that one of the rationales of immunities is to ensure that a State does not sit in judgment of another State, this raison dêtre ceases to apply with international courts, as these are not organs of a particular State. ${ }^{80}$ Arguably, the principle par in parem non habet imperium loses its significance when the jurisdiction over the acts of a sovereign State is not exercised by an equal sovereign State. ${ }^{81}$ Accordingly, it is often asserted that an international court cannot run counter to the principle of equality as it is not a State that is judging another State, but the international community.

Why is the ICC falling within the alleged customary exception for "certain international criminal courts"? Three requirements have been spelled out for a court to be considered of a truly international nature. The first test to elucidate which court constitutes an international criminal court is whether the court is situated within the legal order of international law, rather than the legal order of any specific State. This test can be met by the possession under international law of distinct legal personality. The criteria of international legal personality of an organization are generally considered to be as follows: an association of States equipped with organs; a distinction, in terms of legal powers and purposes, between the organization and its Member States; the existence of legal powers which can be made use of on the international plane. ${ }^{82}$ When these

78 Ibid., par. $33-34$.

79 See Gaeta, "Al Bashir Enjoy Immunity," 322: "the international nature of a criminal court constitutes per se a sufficient ground to assert the unavailability of personal immunities before those international bodies".

8o Gaeta, "Al Bashir Enjoy Immunity," 301-32; Decision on Taylor Immunity, par. 52.

81 ILC, Memorandum prepared by the Secretariat, Immunity of State officials from foreign criminal jurisdiction, 31 March 2008, U.N. Doc. A/CN.4/596, at 39-47.

82 Brownlie, Principles, 677; see also Draft Articles on Responsibility of International Organizations for Internationally Wrongful Acts, Art. 2(a); Reparations for injuries suffered in 
criteria are fulfilled, the organization is considered to have its own personality which entails that it is a subject of international law with its own rights and duties and legal capacity. The legal capacity to enter into agreements with other international persons governed by international law and an autonomous will distinct from that of its members are determinant in respect of immunity. ${ }^{83}$ Indeed, it is this criterion that boost the court from a horizontal to a vertical relationship with States.

The Rome Statute does not only establish a permanent international criminal jurisdiction, it is also the constitutive instrument of an international organization with an international legal personality. ${ }^{84}$ Article 4 Rome Statute clearly establishes that "the Court shall have international legal personality". In the Negotiated Relationship Agreement between the ICC and the UN, the UN explicitly recognizes that the ICC "has international legal personality and such legal capacity as may be necessary for the exercise of its functions and the fulfilment of its purposes." 85 Thus, the ICC is an entity that possesses objective international legal personality and not merely personality recognized by its States parties alone.

A second element that might be required for a court to qualify as truly international in nature is that the court exercises jurisdiction over matters of concern to the international community as a whole. The 'universal jurisdiction conception' is based on this very idea. According to the Preamble of the Statute, the core goals of the Statute is to put an end to impunity for the perpetrators of the most serious crimes of concern to the international community as a whole, which "must not go unpunished". Furthermore, Article 5 Rome Statute makes it clear that " $[t]$ he jurisdiction of the Court shall be limited to the most serious crimes of concern to the international community as a whole". The Rome Statute indeed is not a classical treaty with reciprocal obligations; rather it establishes an international regime where the common intention is in the interest of the international community as a whole.

the service of the United Nations (Advisory opinion) 1949 ICJ Reports 174, the constitutive instrument is not determinative of the international organization possession of legal personality, regard should also be paid to the intention of the drafters of the constitutive instrument; see Jan Klabbers, An Introduction to International Institutional Law (Cambridge University Press, 2009), p. 52-7: for a more elaborated explanation of the theoretical debate underlying the possession of international legal personality.

83 See Gaeta, "Al Bashir Enjoy Immunity," 321.

84 See Rome Statute, Art. 4.

85 Negotiated Relationship Agreement between the ICC and the United Nations of 4 October 2004, Art. 2. 
A third requirement is that if the international community decides to have a specific organ, it must express itself as such. ${ }^{86}$ Otherwise, any criminal jurisdiction that has a legal personality under international law might claim and abuse this position in order to derogate from rules of international law such as immunity ratione personae. Two States can create criminal jurisdiction and assert themselves as guardians of the fundamental interests of the international community. ${ }^{87}$ Robert Woetzel has written that a tribunal is international if it is "instituted by one or a group of nations with the consent and approval of the international community" 88 Woetzel adds that the international community must offer its "clear endorsement" of the tribunal and that approval "cannot be simply assumed". 89

The most convincing evidence that the international community endorses a tribunal would be if part of the UN system. Due to the universal membership of the UN, an act undertaken by all the UN Member States is indeed what most represents the will of the international community. ${ }^{90}$ For instance, the Appeals Chamber of the SCSL in the Decision on Taylor Immunity considered that the Chapter viI status of the Agreement establishing the SCSL made it "an expression of the will of the international community". ${ }^{11}$ Furthermore, according to the SCSL the blessing it received from the SC made it "part of the machinery of international justice". ${ }^{92}$ The "universal jurisdiction conception' however does not claim that the Rome Statute, or a situation triggered under Article 13 (b) of the Statute, has a Chapter viI status. Nonetheless, the ICC "can make a convincing claim to directly embody the "collective" will". ${ }^{93}$ Undeniably, the ICc has a universal reach. The Statute has been negotiated at the universal level. While the ICC is not a UN organ, the Rome Conference was organized and hosted by the UN and 16o States participated to the drafting of the Statute. During a good part of the negotiations of the Rome Statute efforts were made to reach decisions by consensus. ${ }^{94}$ The consensus could not be maintained, but an overwhelming majority of the States approved the text

\footnotetext{
86 Kress, "Immunities under International Law," 246-250.

87 Tunks, "Diplomats or Defendants?," 665; Kress, “Immunities under International Law," 246.

88 Woetzel, The Nuremberg Trials, 49; Heller, The Nuremberg Military Tribunals, 111.

89 Woetzel, The Nuremberg Trials, 49; Heller, The Nuremberg Military Tribunals, 111.

9o The SC when it acts under Chapter VII of the UN charter is, as the supreme organ of the UN, taking decisions that are deemed as the actions of all the UN Member States; UN Charter, Article 24.

91 Decision on Taylor Immunity, par. 38.

92 Ibid.

93 Kress, "Immunities under International Law," 247.

94 Olasolo, The Triggering Procedure, 17.
} 
of the Rome Statute. ${ }^{95}$ It contains an open invitation to any State to adhere to it. Furthermore, the Relationship Agreement between the ICC and the UN has been negotiated in accordance with Article 2 of the Rome Statute and General Assembly Resolution $58 / 79$ of the 9th December $2003 .{ }^{96}$ Finally, the Relationship Agreement between the ICC and the UN, and the use of referrals under Article 13 (b) for Darfur, Sudan and Libya, demonstrate the UN endorsement of the ICC. ${ }^{97}$ Having met the three requirements, the ICC presents itself as the paradigmatic example of a 'truly' international criminal court.

If one accepts that the international nature of the ICC entails that the immunity of high-ranking officials is inapplicable before the Court, Article 27 (2) is indeed a norm that applies to all, irrespective of whether the official is from a State party or not. Indeed, the recognition that Article 27 (2) codifies customary international law serves the 'universal jurisdiction conception' to close the accountability loop which exists for perpetrators of international crimes. However, the crucial point remains. Is the exception for international criminal courts really established under customary international law or is it a travesty of law to avoid a conflict of norms?

The first document where the prosecution of a Head of State before an international criminal jurisdiction is affirmed is in the Report of the Commission on the Responsibility of the Authors of the War and on Enforcement of Penalties (29 March 1919). Although the Commission recommended the establishment of a High Tribunal for the prosecution of the Emperor William II, the report was drafted at a time where the German Kaiser was no longer Head of State. Furthermore, the resultant Article 227 of the Treaty of Versailles noted that " $[t]$ he Allied and Associated Powers will address a request to the Government of the Netherlands for the surrender to them of the ex-Emperor in order that he may be put on trial". The request was never acceded to by the Netherlands.

The Nuremberg Tribunal did not prosecute any serving high-ranking officials either. Joachim Von Ribbentrop, Reich Minister of Foreign Affairs (19381945), and Karl Doenitz, Reich Head of State (2 May 1945 - 23 May 1945) were tried and sentenced by the Nuremberg Tribunal but the proceedings took place after they ceased to be in office, accordingly they, then, only enjoyed immunity ratione materiae. The same applies to Mamoru Shigemitsu, Japanese Minister

\footnotetext{
95 The Rome Statute has been adopted by 120 States, signed by 139 States and at the time of writing ratified by 123 States.

96 UN General Assembly, Relationship Agreement Between the United Nations and the International Criminal Court, 20 August 2004, UN Doc. A/58/874.

97 See also Decision on Malawi Failure to Arrest Al-Bashir, par. 40.
} 
of Foreign Affair (1943-1945) and Hiroshi Oshima, Japanese Ambassador to Berlin (1938-1945), who were tried and sentenced by the International Military Tribunal for the Far East.

Similarly, the ICTR did not address the immunity of Jean Kambanda, former Prime Minister of Rwanda from April 1994 to July 1994, sentenced to life imprisonment for crimes against humanity and genocide, as when indicted in 1997 he was not Prime Minister anymore. ${ }^{98}$ The ICTY indicted Slobodan Milosevic in May 1999 while he was the head of State of the Federal Republic of Yugoslavia from July 1997 to October 200o. The issuance and circulation of this arrest warrant arguably infringed the immunity and inviolability then enjoyed by Milosevic under international law. But, no State objected that the ICTY violated the rule on immunity ratione personae by issuing and circulating the arrest warrant on the then President of the F RY. ${ }^{99}$ Gaeta thus argues that States did not object because they considered that immunities did not apply before international criminal courts and tribunals, even absent a specific provision to that effect in the ICтY's Statute. ${ }^{100}$ However, the arrest warrant was enforced and Milosevic transferred into the custody of the ICTY only in June 2001, i.e. when he enjoyed immunity ratione materiae. Furthermore, in the Decision on Preliminary Motions the ICTY Trial Chamber refers to Milosevic's criminal responsibility not to its amenability to the jurisdiction of the Tribunal when the indictment was first issued. The ICTY did not review whether the indictment of June 1999 was in accordance with international law, but whether it lacked competence by reason of Milosevic's status as former Head of State. ${ }^{101}$ Accordingly, it is debatable whether there were any precedents at the time of the Arrest Warrant Case of an international criminal court explicitly overruling the immunity ratione personae of an incumbent high-ranking State official. ${ }^{102}$

The Arrest Warrant Case was however relied on by the Special Court for Sierra Leone when it ruled that the - then - incumbent President of Liberia, Charles Taylor, was not entitled to immunity ratione personae. ${ }^{103}$ The SCSL found that because it qualified as an international criminal court, Taylor's official position as an incumbent head of Sate at the time when the proceedings

\footnotetext{
98 Prosecutor v. Kambanda, Case No. ICTR-97-23-S, Judgment and Sentence (Sept. 4, 1998); Prosecutor v. Kambanda, Case No. ICTR-97-23-I, Judgment (Oct. 19, 2000).

99 Gaeta, "Al Bashir Enjoy Immunity," 315-322.

100 Gaeta, "Al Bashir Enjoy Immunity," p. 321.

101 Prosecutor v. Milosevic, Case No. IT-02-54, Decision on Preliminary Motions (Nov. 8, 2001), par. $26-34$.

102 See also Cimiotta, "Immunità personali dei Capi di Stato," 1105- 1112; Kress, "Immunities under International Law," 253.

103 Decision on Taylor Immunity, par. 37-42.
} 
were initiated against him was not a bar to his prosecution. ${ }^{104}$ The Chamber further held that Article 6(2) of the SCSL Statute, which is substantially similar to Article 7 (2) of the ICTY Statute, Article 6 (2) of the ICтR Statute and Article $27(1)$ of the Rome Statute, relates to immunity ratione personae. To sum up, this is the only case before Decision on Malawi Failure to Arrest Al-Bashir where the Arrest Warrant Case's customary exception to immunity ratione personae for courts of an internal nature is explicitly affirmed.

Claus Kress has nevertheless advocated that the irrelevance of immunity ratione personae before the ICC is premised on what he coins as "modern custom." 105 Under this approach, which consists of focusing more on the opinio juris element of customary international law than on State practice, it is claimed that "a weighty case can be made for the crystallization of a customary international criminal law exception from the international law immunity ratione personae in proceedings before a judicial organ of the international community."106

However, it appears that not all States in the international community believe that Article $27(2)$ is established in customary international law. In addition to the United States' firm opposition to the ICC's exercise of jurisdiction over its current or former officials, the practice of States party to the African Union (AU) appears to demonstrate that the customary status of Article 27(2) is hotly contested. ${ }^{107}$ Following the issuance of the first arrest warrant by the ICC for the President of Sudan, Omar Al-Bashir, the AU took a number of decisions calling upon its State parties, especially States party to the Rome Statute, not to arrest and surrender Al-Bashir. ${ }^{108}$ The central dispute between the AU

104 Decision on Taylor Immunity, par. 53.

105 Kress, "Immunities under International Law," 251.

106 Kress, "Immunities under International Law," 254; Nonetheless, he remains duly cautious and acknowledges that the custom he believes to have come into existence is affected by a "relatively high vulnerability to change because the hard practice that contributed to its crystallization is fairly scarce".

107 African Union, Press Release No. 002/2012 (Jan. 9, 2012).

108 African Union, Assembly, Decision on the Meeting of African States Parties to the Rome Statute of the International Criminal Tribunal, Doc. Assembly/AU/13(XIII), 3 July 2009, Assembly/AU/Dec.245(XIII) Rev. 1, par. 10; African Union, Assembly, Decision on the Progress Report of the Commission on the Implementation of Decision Assembly/ AU/Dec.27o(XIV) on the Second Ministerial Meeting on the Rome Statute of the International Criminal Court (ICC), Doc. Assembly/AU/10(XV), 27 July 2010, Assembly/AU/ Dec.296(Xv), paras. 5-6; African Union, Assembly, "Decision on the Implementation of the Decisions on the International Criminal Court (ICC) Doc. EX.CL/639(XVIII)", 30-31 January 2011, Assembly/AU/Dec.334(XVI), par. 5; African Union, Assembly, Decision on the Implementation of the Assembly Decisions on the International Criminal Court, Doc. EX.CL/67o(XIX), 30 June-1 July. 2011 Assembly/AU/Dec.366(XVII), 3 J June-1 July 2011, par. 
and the ICC is Al-Bashir's immunity as a Head of State which Al-Bashir and the AU opine protects heads of States not party to the Statute from ICC jurisdiction. The AU Assembly has decided that "no charges shall be commenced or continued before any International Court or Tribunal against any serving AU Head of State or Government or anybody acting or entitled to act in such capacity during their term of office." ${ }^{109}$ In the same decision the Assembly voted that AU States parties to the ICC propose at the 12th session of the ICC Assembly of States Parties an amendment to Article 27 (2). ${ }^{110}$ The AU furthermore adopted the Malabo Protocol which establishes a criminal section within the African Court of Justice and Human Rights - exercising competing jurisdiction with the ICC - and grants immunity ratione personae to high-ranking State officials. ${ }^{111}$ The opinio juris of States party to the AU, which includes States party to Rome Statute, shows that the customary nature of Article 27 (2) Rome Statute is seriously disputed.

If the customary status of Article 27 (2) is not recognized, the conflict between the ICc's exercise of jurisdiction over a high-ranking State official not party to the Statute and the immunity of the latter becomes genuine and the 'universal jurisdiction conception' offers no way to resolve it. The scant evidence of State practice and opinio juris are pointing out that a customary exception based on the international nature of the court is not established in customary international law. ${ }^{112}$ Accordingly, only the SC is able, thanks to its Chapter vII powers, to remove the immunity of high-ranking State officials without a waiver from his State.

Even the claim that the crimes of which the accused is charged are prohibited by jus cogens norms is to no avail. In Jurisdictional Immunities of the State (Germany v. Italy: Greece intervening) the ICJ clearly stated that the jus cogens nature of a norm cannot deprive a State from the procedural immunity it is entitled to under international law. ${ }^{113}$ Thus, the superior hierarchy of jus cogens

5; Ext/Assembly/AU/Dec.1(Oct.2013), Decision on Africa's Relationship with the International Criminal Court (ICC), par. 10 (i).

109 Ext/Assembly/AU/Dec.1(Oct.2013), Decision on Africa's Relationship with the International Criminal Court (ICC), par. 10 (i).

110 Ext/Assembly/AU/Dec.1(Oct.2013), Decision on Africa's Relationship with the International Criminal Court (ICC), par. 10 (vi), (vii).

1112014 Draft Protocol on the Amendments to the Protocol on the Statute of the African Court of Justice and Human Rights, AU EX.CL/846 (XXV), Article 46A bis; see also Pedretti, Immunity, 224-229.

112 See also Pedretti, Immunity, 295-296.

113 Jurisdictional Immunities of the State (Germany v. Italy: Greece intervening), 3 February 2012, Judgment, ICJ Report, par. 95: In Arrest Warrant Case, par. 58, 78., the Court held, albeit without express reference to the concept of jus cogens, that the fact that a Minister for Foreign Affairs was accused of criminal violations of rules which undoubtedly possess 
norms in international law cannot be used in order to resolve the conflict with the immunity ratione personae of high-ranking State officials. Indeed, jus cogens norms and procedural immunities do not clash. ${ }^{114}$

However, one should always bear in mind that immunity from jurisdiction does not mean impunity. Immunity ratione personae ceases when the highranking State official stops holding office. Subsequently, the official may claim immunity ratione materiae for the acts he or she committed on behalf of the State. Immunity ratione materiae, on the other hand, is a substantive immunity that exempts the official to whom it applies from all criminal responsibility for their official acts. In such cases one may claim that immunity ratione materiae is of no avail for prohibitions that are jus cogens. However, such a claim is not even necessary since it is uncontested that Article 27 (1) codifies customary international law. All previous international(ized) criminal tribunals or courts contained a similar provision and applied them several times to individuals who were in principle entitled to immunity ratione materiae.

\section{The Arrest and Surrender of an Official Entitled to Immunity to the ICC}

The exercise of jurisdiction by international criminal courts over officials entitled to immunity is often separated from the cooperation of States to arrest and surrender those same officials. However, international criminal courts do not have their own enforcement authorities. As such, they rely on States to enforce their arrest warrants. To use Antonio Cassese's analogy international tribunals are "like a giant without arms and legs - [they] need artificial limbs to walk and work. And these artificial limbs are State authorities. If the cooperation of States is not forthcoming, the [international tribunal] cannot fulfil its functions." ${ }^{115}$ Indeed, if States do not cooperate with the ICc by enforcing the arrest warrants of the Court, any exercise of its jurisdiction will remain a legal fiction. ${ }^{116}$ However, in order to enforce an ICC arrest warrant States must exercise jurisdiction over the relevant individual.

the character of jus cogens did not deprive the Democratic Republic of the Congo of the entitlement which it possessed as a matter of customary international law to demand immunity on his behalf.

114 Arrest Warrant Case, par. 6o.

115 Cassese, "Current Trends," 13.

116 Note that the ICC can also issue a summons under Article $5^{8}$ (7) Rome Statute if it believes that it is sufficient to ensure the person's appearance. 
One of the distinguishing features of international crimes is that such crimes are often committed by State officials. For instance, in the case of war crimes, many of the perpetrators will have been acting as soldiers or officials exercising State authority.117 The definition of torture in the Convention against Torture requires that the act be "inflicted by or at the instigation of or with the consent or acquiescence of a public official or other person acting in an official capacity."118 The chapeau of crimes against humanity requires a widespread or systematic attack against the civilian population. ${ }^{119}$ Although the ICTY held that it is not required to prove that the crimes were related to a State policy, it recognized that "in the conventional sense of the term, they cannot be the work of isolated individuals alone." ${ }^{120}$ The Rome Statute, for its part, in Article $7(2)$ (a) requires that the attack against any civilian population "must be pursuant to or in furtherance of a State or organizational policy."121 While the ICC case law shows that crimes against humanity can be committed by non-State actors, the contextual elements and gravity of patterns of conduct that constitute international crimes make it more likely than not that they have been committed by individuals with access to State's apparatus. ${ }^{122}$

Notwithstanding that contextual element, the ICJ in the Arrest Warrant Case found that States violate their obligation under international law towards another State if they fail to respect the immunities of the latter State's officials. ${ }^{123}$ Thus, an ICC arrest warrant calling upon State parties to arrest and surrender an official from a non-party State may conflict with the latter's immunity ratione personae and ratione materiae.

The ICJ Arrest Warrant Case even cast doubt upon the issue of whether there is a specific exception to immunity ratione materiae for international crimes. ${ }^{124}$ However, most international legal scholarship and jurisprudence considers that it is established under customary international law that

\footnotetext{
117 Akande, "Nationals of Non-Parties,." 634.

118 Convention against Torture and Other Cruel, Inhuman or Degrading Treatment or Punishment, Art. 1.

119 See Rome Statute, Art. 7; ICTY Statute, Art. 5; ICTR Statute, Art. 3.

120 Prosecutor v. Nikolic, Case No. IT-94-2-R61, Review of Indictment Pursuant to Rule 61 of the Rules of Procedure and Evidence (Oct. 20, 1995), par. 26.

121 See Situation in the Republic of Kenya, Case No. ICC-o1/og, Decision Pursuant to Article 15 of the Rome Statute on the Authorization of an Investigation into the Situation in the Republic of Kenya (Mar. 31, 2010), par. 117; and, Dissenting Opinion of Judge Hans-Peter Kaul, par. 65

122 ILC, Commentary to the Draft Code of Crimes Against the Peace and Security of Mankind U.N. Doc. A/CN.4/SER.A/1991/Add.l (Part 2), Art. 2.

123 Arrest Warrant Case, par. 54, 70.

124 See supra footnotes $12-18$ and accompanying texts.
} 
immunity ratione materiae is not available in domestic proceedings concerning international crimes. ${ }^{125}$ The ILC in its study on the immunity of State officials from foreign criminal jurisdiction provisionally adopted Draft Article 7 which holds that 'Immunity ratione materiae from the exercise of foreign criminal jurisdiction shall not apply in respect of the following crimes under international law: (a) crime of genocide; (b) crimes against humanity; (c) war crimes; (d) crime of apartheid; (e) torture; (f) enforced disappearance... ${ }^{126}$ The Draft Article 7 was not adopted without debate. Some ILC members asserted that customary international law did not support the existence of limitation and exceptions to immunity ratione materiae, ${ }^{127}$ while others contended that the crime of aggression should have been added to the list of crimes for which immunity did not apply. ${ }^{128}$ It has indeed been argued that if a crime attracts universal jurisdiction under customary international law, immunity ratione materiae does not apply to such conduct. ${ }^{129}$ Such argument entails that the customary character of the charges against an official from a State not party to the Rome Statute need to be checked for the latter's immunity not being a bar to his arrest and surrender to the Court. As shown earlier, this might prove to be challenging for certain crimes defined in the Rome Statute - aggression is indeed in the list of Rome Statute crimes which are said to be broader than their customary definition. ${ }^{130}$

In any event, the relevance of immunity ratione materiae of non-party State officials from arrest and surrender has not been raised before the ICC yet. In contrast with the 'Al-Bashir fiasco', States failing to arrest Abdel Raheem Muhammad Hussein, Minister of National Defense in the Republic of the Sudan, did not invoke the immunity of the latter but their inability to take prompt action. ${ }^{131}$ These States' omission to refer to Hussein's immunity can be taken as recognition that immunity ratione materiae does not bar the enforcement of an ICC arrest warrant.

\footnotetext{
125 Pedretti, Immunity, 307-308.

126 ILC, Report of the Work of the Sixty-Ninth Session, Doc. A/72/10 (2017), par. 68-141.

127 Ibid., par. 102-103.

128 Ibid., par. 122.

129 Akande and Shah, "Immunities of State Officials," 815-852.

130 See Chapter 2.

131 See Prosecutor v. Hussein, Case No. ICC-02/05-01/12-21, Decision on the cooperation of the Central African Republic regarding Abdel Raheem Muhammad Hussein's arrest and surrender to the Court (Nov. 13 2013); Prosecutor v. Hussein, Case No. ICC-O2/05-01/12-21, Decision on the Cooperation of the Republic of Chad Regarding Abdel Raheem Muhammad Hussein's Arrest and Surrender to the Court (Nov. 13, 2013).
} 
Nonetheless, the confusion caused by the Arrest Warrant Case's obiter dicta is exacerbated by the paragraphs in SC Resolutions 1593 and 1970, referring the situations in Darfur and Libya to the ICC, by which the SC:

Decides that nationals, current or former officials or personnel from a contributing State outside Sudan [the Libyan Arab Jamahiriya, in SC 1970] which is not a party to the Rome Statute of the International Criminal Court shall be subject to the exclusive jurisdiction of that contributing State for all alleged acts or omissions arising out of or related to operations in Sudan [Libyan Arab Jamahiriya, in SC 1970] established or authorized by the Council or the African Union, unless such exclusive jurisdiction has been expressly waived by that State. ${ }^{132}$

These operative paragraphs clearly attempt to provide immunity for any nonparty State's official (outside of Sudan and Libya, respectively) from the ICc's jurisdiction and from foreign domestic criminal jurisdiction.

The effects on the ICC of these 'immunity for peacekeepers' paragraphs will be discussed in the next chapter. Nevertheless, two aspects deserve attention as to immunity ratione materiae. First, if international crimes were within the scope of immunity ratione materiae, the SC would not have needed to 'decide' that current and former officials entitled to such immunity were subject to the 'excusive jurisdiction' of their States. Indeed, in these resolutions the SC attempts by using its Chapter viI powers to change the state of the international law on immunities. In other words, these paragraphs imply that by default the ICC had jurisdiction over these current or former officials.

Secondly, the use of 'exclusive jurisdiction' in the SC resolutions is rather disturbing as it attempts to once again create new law. The SC used similar language in SC Resolution 1487 which established a Multinational Force for Liberia but also decided that current or former officials or personnel from a contributing State "shall be subject to the exclusive jurisdiction of that contributing State". ${ }^{133}$ During that meeting Mexico, Germany and France abstained from voting in favor of the resolution despite their support for the Multinational Force on the basis that the 'immunity for peacekeepers' paragraph was not in accordance with international law and their domestic law. ${ }^{134}$ Indeed, they contested that any State had 'exclusive jurisdiction' over their current or former officials or personnel. At the meeting on the adoption of SC Resolution

\footnotetext{
132 SC Res. 1593, par. 6; SC Res. 1970, par. 6.

133 SC Res. 1497 of 1 August 2003, UN Doc. S/RES/1497, par. 7.

134 Security Council, 4803rd meeting, UN Doc. S/PV.4803 (Aug. 1, 2003).
} 
1593, France emphasized "that the jurisdictional immunity provided for in the text we have just adopted obviously cannot run counter to other international obligations of States and will be subject, where appropriate, to the interpretation of the courts of my country."135 The obligations France referred to were those arising inter alia from the Geneva Conventions, the Convention against Torture and obviously the Rome Statute. Clearly, if one applies Article 103 UN Charter, the obligation of France arising from the SC Resolution prevails over its obligations under any other international agreement. ${ }^{136}$ Thus, it is not international law on immunities that recognizes that immunity ratione materiae is a bar to foreign criminal proceedings even for international crimes but the $\mathrm{SC}$ resolutions providing for immunity in respect of specific operations established or authorized by the SC. However, as we will see in chapter 5 , it is for the ICC to consider whether the immunity provided in these SC resolutions is an admissible bar to its jurisdiction.

As we have seen above, the ICJ also held in the Arrest Warrant Case that high-ranking State officials entitled to immunity ratione personae, enjoy full immunity from criminal jurisdiction and inviolability when travelling abroad. While the ICJ referred in obiter dicta to the unavailability of immunities in proceedings before certain international criminal courts, it did not address the issue of whether the same immunities are available when a State enforces an ICC arrest warrant.

The Rome Statute makes it clear that its States parties are under a general obligation to cooperate fully with the ICC in the investigation and prosecution of crimes within the jurisdiction of the Court. ${ }^{137}$ However, while States parties are to comply with requests for arrest and surrender, ${ }^{138}$ the drafters of the Rome Statute restricted the discretion of the Court to issue requests for arrest and surrender of an official from a non-party State. Indeed, according to Article 98 (1) Rome Statute:

The Court may not proceed with a request for surrender or assistance which would require the requested State to act inconsistently with its obligations under international law with respect to the State or diplomatic

\footnotetext{
135 SC 5158th meeting, UN Doc. S/PV.5158 (Mar. 31, 2005)

136 This would apply even if France had voted against the resolution, see Advisory Opinion, Legal Consequences for States of the Continued Presence of South Africa in Namibia (South West Africa) notwithstanding Security Council Resolution 276 (1970), ICJ Reports, p. 16, par. 116.

137 Rome Statute, Art. 86.

138 Rome Statute, Art. 59 (1) and 89 (1).
} 
immunity of a person or property of a third State, unless the Court can first obtain the cooperation of that third State for the waiver of the immunity.

The purpose of this provision is to restrict the ICC's power to request a State to act inconsistently with its obligation under international law. Indeed, there was an uncertainty in Rome at the time of drafting the Statute as to whether international law provided an exception to immunities of high-ranking State officials when States had to enforce the decision of an international criminal court. ${ }^{139}$ Since a solution needed to be found in order to conclude the drafting of the Statute, States left the issue of the existence of a conflict to the Court. ${ }^{140}$ Article 98 of the Rome Statute leaves to the Court the competence to determine, as the case arises, whether international law provides an exception to State and diplomatic immunity and whether it should obtain a waiver of immunity. Thus, if the ICC assesses that a request for surrender or assistance forces the requested State to violate its obligation under international law towards a third State, the ICC has to either first obtain a waiver of immunity from the third State or not issue the request. ${ }^{141}$

It is generally accepted that States party to the Rome Statute have removed their immunity in respect of the ICC and of other States parties enforcing an ICC request for arrest and surrender. ${ }^{142}$ By ratifying the Rome Statute, in particular the norm contained in Article 27(2) of the Rome Statute, States have renounced invoking the immunity of their high-ranking State officials before the ICC. Further, given that the Statutes provides that the Court can request for the arrest and surrender of their officials while abroad, ${ }^{143}$ this removal extends to foreign national authorities enforcing an ICC arrest warrant. ${ }^{144}$ Accordingly, a State party can arrest and surrender a high-ranking official of another State

\footnotetext{
139 Kress, "Immunities under International Law," 232-234.

140 Ibid..

141 See Gaeta, "Al Bashir Enjoy Immunity," 327-329; see also Arrest Warrant Case, par. 70, 71, about the issuance and circulation of an arrest warrant against a person entitled to immunity and inviolability under international law; However, see Article 87(5); Kress and Prost, "Article 98," 16o6; Kress, "Immunities under International Law," 232-234.

142 Gaeta, "Al Bashir Enjoy Immunity," 328.

143 Rome Statute, Art. 89.

144 Gaeta, "Al Bashir Enjoy Immunity," 325-327; Akande, "International Law Immunities," 422; Schabas, Commentary on the Rome Statute, 73-74; Wirth, "Immunity for Core Crimes," 452-454; e.g. see the United Kingdom's International Criminal Court Act (2001), art. 23 (1) which reads: "[a]ny state or diplomatic immunity attaching to a person by reason of a connection with a state party to the ICC Statute does not prevent proceedings ... [related to arrest and surrender] in relation to that person".
} 
party without violating the immunity from criminal jurisdiction and the inviolability normally enjoyed by the official under international law.

On the other hand, States not party to the Rome Statute have not renounced to the immunity and inviolability their officials enjoy under international law. Thus, their high-ranking officials would be immune from prosecution before international criminal courts - if one considers that such immunity exists - and even more so from arrest and surrender by a foreign national authority. The next sections assess the interaction of the 'Chapter VII conception' and the 'universal jurisdiction conception' with the latter impediment.

\subsection{Chapter VII Conception}

It is generally acknowledged that the immunity ratione personae of highranking State officials under customary international law is a bar to any act of authority from a foreign domestic court. Thus, the arrest and surrender to the ICC of high-ranking officials from non-party States is apparently in conflict with this rule of customary international law. A clear exception to this rule is that the State of the official has waived its immunity. Ratification of the Rome Statute entails that the concerned State removed the immunity of its officials with respect to the ICC and States enforcing its arrest warrants. Indeed, waivers of immunities are not required with respect to States Parties. Accordingly, Article 98 (1) Rome Statute speaks only of "the State or diplomatic immunity of a person or property of a third State". With respect to third States - i.e. States not party to the Rome Statute - they may issue a waiver of the immunity of the State officials under an arrest warrant and thus the States parties may arrest and surrender the former's official without acting inconsistently with their obligations under international law. The waiver requirement does not apply however to States that issued a declaration of acceptance of the Court's jurisdiction, though they are not States party to the Rome Statute. This is so, because by accepting the Court's jurisdiction they consent to the Statute provisions, including Article 27 and the provisions relating to cooperation and judicial assistance.

The effects of a SC referral, accompanied with an obligation to cooperate fully, are to some extent similar to a declaration of acceptance under Article 12 (3). However, the 'Chapter vil conception' of a referral under Article 13 (b) is that the legal basis of the Court's exercise of jurisdiction and request for cooperation stem directly from the UN Charter. In Decision on DRC Failure to Arrest Al-Bashir, Pre-Trial Chamber II held that a referral by the SC acting under Chapter VII of the UN Charter with an explicit obligation "to cooperate fully with the Court" implies that the immunity ratione personae of the 
high-ranking State official from the targeted State is waived for proceedings before the Court. ${ }^{145}$ Furthermore, given that immunities are an impediment to the official's arrest and surrender, the SC by requiring cooperation has also implicitly waived the immunity of the officials from the concerned State in respect of States enforcing an arrest warrant issued by the ICc. Thus, the argument goes, an obligation under Chapter VII to cooperate with the Court even without explicitly containing the obligation to waive the immunity of State officials - implies a waiver of immunity. Such waivers, if they are not to be futile, must extend to any proceedings related to the ICC's exercise of jurisdiction including States enforcing ICC arrest warrants. ${ }^{146}$ In other words, the obligation to cooperate with the Court must have horizontal effect due to the Court's reliance on the cooperation of States to exercise jurisdiction and fulfil its mandate.

Accordingly, the apparent conflict can be avoided, thanks to the Chapter VII powers underlying the SC referral. Furthermore, this reading of the effects of the SC resolution upon Sudan's immunity has the advantage of directly answering to Article 98 of the Rome Statute, which requires the Court not to ask States to act inconsistently with international law immunities, unless such immunities are waived. However, such a conflict-avoidance technique has not been accepted by all. Indeed, the SC could have decided in its resolutions referring the situation to the ICC to explicitly lift immunities. ${ }^{147}$ If it had done so no ambiguity would have remained as to the relevance of immunities from the execution of an ICC arrest warrant. ${ }^{148}$

The implied waiver theory has its flaws. As South Africa argued during the proceeding on Decision on South Africa Failure to Arrest Al-Bashir, Article 32(2) of the Vienna Convention on the Law of Diplomatic Relations specifies that a waiver of immunity must always be express. ${ }^{149}$ The claim has also been made that "[i]f the UNSC intended to remove immunity, it could have clarified the situation by adopting another resolution." 150 To resolve such argument, PreTrial Chamber II, in Decision on South Africa Failure to Arrest Al-Bashir, found that by deciding, under Chapter VII of the UN Charter, that Sudan shall cooperate fully with the Court, the SC has imposed an obligation upon Sudan to

\footnotetext{
145 Decision on DRC Failure to Arrest Al-Bashir, par. 29.

146 Akande, "Impact on Al-Bashir's Immunities," 333.

147 Aloisi, "A Tale of Two Institutions,"154.

148 Decision on the Progress Report of the Commission on the Implementation of the Assembly Decisions on the ICc, Doc, EX. EX.CL/710 (XX), Assembly/AU/Dec.397 (XVIII), 29-30 January 2012, par. 10.

149 Decision on South Africa Failure to Arrest Al-Bashir, par. 36.

150 Ibid., par. 37; see also Tladi, "The Duty on South Africa," 1043.
} 
abide by the Statute and cooperate with the Court. ${ }^{151}$ Although such obligation originates in the SC resolution, its effect is that for the limited purpose of the situation referred, Sudan has rights and duties analogous to those of States party to the Statute. 152 "One consequence of this" writes the Pre-Trial Chamber, "is that Article 27(2) of the Statute applies equally with respect to Sudan, rendering inapplicable any immunity on the ground of official capacity belonging to Sudan that would otherwise exist under international law."153 Given that immunities which Sudan normally enjoys have been made inapplicable as a result of Article 27 (2) and the SC resolution imposing the Rome Statute over Sudan, Article 98 has no bearings on such type of situations. The Chamber recognized that this was "an expansion of the applicability of an international treaty to a State which has not voluntarily accepted it as such."154 Nonetheless, according to the Chamber, this finding "is in line with the Charter of the United Nations." 155

One advantage of this approach is that it does not entirely depend on the SC's actual intention when referring a situation to the Court. ${ }^{156}$ The Rome Statute is indeed spelling out the legal framework under which the Court must operate, even when triggered under Article 13 (b) of the Rome Statute. ${ }^{157}$ Thus,

by referring the Darfur situation to the Court pursuant to article 13(b) of the Statute, the Security Council of the United Nations has also accepted that the investigation into the said situation, as well as any prosecution arising therefrom, will take place in accordance with the statutory framework provided for in the Statute, the Elements of Crimes and the Rules as a whole. ${ }^{158}$

\footnotetext{
151 Decision on South Africa Failure to Arrest Al-Bashir, par. 87.

$15^{2}$ Ibid., par. 88.

153 Ibid., par. 91

154 Ibid., par. 89,

155 Ibid, par. 89.

156 Ibid., par. 85 .

157 See Chapter 5 .

158 Decision to Issue an Arrest Warrant against Al-Bashir, par. 44; Decision on South Africa Failure to Arrest Al-Bashir, par. 85-86; Prosecutor v. Gaddafi and Al-Senussi, Case No. ICCo1/11-o1/11-163, Decision on the postponement of the execution of the request for surrender of Saif Al-Islam Gaddafi pursuant to article 95 of the Rome Statute (Jun. 1, 2012), par. 28-29; , The Prosecutor v. Banda and Jerbo, Case No. ICC-o2/o5-o3/o9-169, Decision on 'Defence Application pursuant to articles 57(3)(b) \& 64(6)(a) of the Statute for an order for the preparation and transmission of a cooperation request to the Government of the Republic of the Sudan' (Jul. 12011$)$, para. 15.
} 
While this line of reasoning manages to avoid the controversies over the waiver theory, a member of the Chamber, ${ }^{159}$ some scholars, States and the AU remain unconvinced that a referral under Article 13 (b), even when accompanied by a Chapter VII obligation to cooperate with the Court, removes ipso facto the immunities of high-ranking State officials from their arrest and surrender by other States. ${ }^{160}$ In particular, Jordan has appealed the Pre-Trial Chamber finding - which has the same ratio decidendi as the Decision on South Africa Failure to Arrest Al-Bashir - that it failed to arrest Al-Bashir. ${ }^{161}$ Jordan is indeed arguing that the intent of the SC when referring the situation cannot be 'immaterial' - ${ }^{162}$ a view that found support in some amicus curiae submitted to the Court. ${ }^{163}$ The Appeals Chamber will thus have to decide whether any of the line of reasoning applied by the Pre-Trial Chambers are correct or whether the SC when referring a situation should have explicitly removed the immunities of the concerned State's officials for the latter not to have bearings on the arrest and cooperation by other States.

Broadly, two main counter-arguments to the Pre-Trial Chambers' interpretations have been spelled out in the literature, which have been to a certain extent used by South Africa and Jordan in their proceedings before the Court. First, the SC does not have the power to remove the immunities of officials from States not party to the Rome Statute, as those immunities are enshrined in customary international law. ${ }^{164}$ Kiyani argues that the UN Charter does not have primacy over customary international law, but only over international

159 Decision on South Africa Failure to Arrest Al-Bashir, Minority Opinion of Judge Marc Perrin de Brichambault.

160 See African Union Commission, Press Release No oo2/2012 (Jan. 9, 2012), p. 2.

161 Prosecutor v. Al-Bashir, Case No. ICC-02/05-01/o9-309, Decision under article 87(7) of the Rome Statute on the non-compliance by Jordan with the request by the Court for the arrest and surrender of Omar Al-Bashir (Dec. 11, 2017); Prosecutor v. Al-Bashir, ICC-o2/o5o1/o9-326, The Hashemite Kingdom of Jordan's appeal against the "Decision under article $87(7)$ of the Rome Statute on the non-compliance by Jordan with the request by the Court for the arrest and surrender [of] Omar Al-Bashir", (Mar. 12, 2018).

162 See Prosecutor v. Al Bashir, PTC II, The Hashemite Kingdom of Jordan's Notice of Appeal of the Decision under Article 87(7) of the Rome Statute on the Non-Compliance by Jordan with the Request by the Court for the Arrest and Surrender of Omar Al-Bashir; or, in the Alternative, Leave to Seek Such an Appeal, ICC-o2/o5-o1/o9, 18 December 2017, par. 31.

163 E.g. Prosecutor v. Al Bashir, Case No. ICC-O2/05-O1/o9 OA2, Request by Professor Roger O'Keefe for leave to submit observations on the merits of the legal questions presented in 'The Hashemite Kingdom of Jordan's appeal against the "Decision under article 87(7) of the Rome Statute on the non-compliance by Jordan with the request by the Court for the arrest and surrender [of] Omar Al-Bashir"' of 12 March 2018 (ICC-o2/o5-01/o9-326) (Apr. $192018)$.

164 Kiyani, "Al-Bashir \& the ICC," 478-480. 
agreements. Thus, he concludes that the SC cannot impose the conventional exception to the customary rule on immunity of high-ranking State officials to its Member States. Second, even if the SC has such power, the wording of the SC referrals, and the accompanying obligation to cooperate are too vague to entail a waiver or removal of immunity. In other words, the SC should have explicitly waived the international law immunities of State's officials. ${ }^{165}$ Both arguments thus lead to a genuine conflict, where immunity prevails.

These counter-arguments are however not convincing. Regarding the first argument, it needs to be highlighted that the SC is entitled to deviate from customary international law when acting under Chapter VII. ${ }^{166}$ Article 1(1) of the UN Charter makes clear that the SC is not obliged to act in conformity with the principles of international law when taking measures for the prevention and removal of threats to the peace. ${ }^{167}$ Moreover, whether SC obligations will prevail over customary obligations, depends on if a strict understanding of the effect of Article 103 of the UN Charter is adopted - Article 103 speaks of the primacy of the UN Charter over "international agreements". But this legalistic approach has been widely rejected in light of the SC practice. ${ }^{168}$ Furthermore, given that the purpose of Article 103 is to ensure that Charter obligations are respected, ${ }^{169}$ there is no logical reasons for still presuming that the obligations of the Charter prevail over treaties but not over customs.

With respect to the second argument, De Wet observes that past practice of the SC reveal that resolutions under Chapter vII do not explicitly stipulate what the enforcers of such resolution may do, but what they may not do. ${ }^{170}$ For instance, when the SC authorizes Member States to use military force it broadly authorizes 'all necessary means' or 'all necessary measures', specifies the purpose of such measures, and then indicates the limits of such measures. ${ }^{171}$ Accordingly, immunities would not have been necessarily waived (or inapplicable) if the SC had specifically provided that the immunities of all State officials, including States obliged to cooperate fully pursuant to the resolution, were not affected. For instance, both SC resolution 1593 and 1970 attempt to exclude the Court's jurisdiction over officials of non-party States (other than

165 Tladi, 'The Duty on South Africa,' 1043; O'Keefe, International Criminal Law, par. 14.97.

166 De Wet, Chapter VII Powers, 182.

167 O'Keefe, International Criminal Law, par. 12.31.

168 See e.g. Schweigman, The Authority of the Security Council, 196; Fassbender, The Constitution of the International Community 120; ILC, Fragmentation Study, par. 344-345; Akande, "Impact on Al-Bashir's Immunities," 348.

169 Conforti, United Nations, 292.

170 De Wet, "The Implications of President Al-Bashir," 1061.

171 Ibid., at 1061; see also SC Res. 1973 of 11 March 2011, UN Doc. S/RES/1973, par. 4. 
Sudan and Libya, respectively). ${ }^{172}$ Indeed, the SC did not put such restriction with regards to officials from Sudan or Libya, quite the contrary.

Indeed, this counter-argument fails to acknowledge the scope of the obligation to 'cooperate fully' imposed on Sudan. As seen above, one fundamental difference between the ad hoc tribunals and SC referrals is that the SC decided to refer the situation in Darfur and Libya to the ICC without obliging all UN Members States to cooperate with the Court, but only the territorial State where the situation was taking place. Other States are therefore not obliged to cooperate with the Court, pursuant to the SC resolutions. States parties, however, remain obliged to cooperate with the Court, as provided by the Rome Statute.

One State that clearly has an obligation to arrest and surrender any of its nationals, regardless of their official position is the State ordered by the SC to cooperate fully with the Court. As Akande observes, by requiring Sudan and Libya to cooperate fully with the Court, "the SC resolution explicitly subjects Sudan [and Libya] to the requests and decisions of the Court."173 It is clear that the terms "cooperate fully" are taken verbatim from Article 86 Rome Statute, the first article of Part 9 on the International Cooperation and Judicial Assistance. ${ }^{174}$ In cases of SC referrals, imposing an obligation to cooperate fully, Article 86 must be applied to the targeted non-party State, which pursuant to the relevant resolution of the SC, shall, in "accordance with the provision of [the] Statute, cooperate fully with the Court in its investigation and prosecution of crimes" committed in the context of the referred situation. ${ }^{175}$ By reading down Article 86 to include States targeted by the SC, it becomes possible to apply mutatis mutandis all the provisions of Part 9 to this State. Article 88 of the Rome Statute is of particular importance here. Article 88 stipulates that States Parties shall ensure that there are procedures available under their national law for all of the forms of cooperation which are specified under Part 9. Article 88 must also be adapted to include the targeted non-party State, which for this particular situation, shall take all required measures under national law, including lifting immunities, to ensure that an ICC request for arrest and surrender can be enforced. It must

172 SC Resoltuion 1593, par. 6; SC Resolution 1970, par. 6. Whether these paragraphs bind the Court is addressed in Chapter 4.

173 Akande, "Impact on Al-Bashir's Immunities," 341.

174 Akande, "The Effect of Security Council Resolutions and Domestic Proceedings," 309.

175 Rome Statute, Art. 86; see also Prosecutor v. Banda and Jerbo, Case No. ICC-o2/05-03/ 09-169, Decision on "Defence Application pursuant to Articles 57(3)(b) \& 64(6)(a) of the Statute for an order for the preparation and transmission of a cooperation request to the Government of the Republic of the Sudan" (Jul. 1, 2011), par. 15 . 
be noted that even if the State has not undertaken these measures, it cannot serve as a justification for a refusal to comply with a request for arrest and surrender. ${ }^{176}$ In other words, an arrest warrant issued by the Court in the context of the referred situation and sent to the State targeted by the Chapter VII obligation to 'cooperate fully' entails that this State even if not party to the Rome Statute must arrest and surrender the suspect, irrespective of his official capacity.

States parties also have such obligation if the official is from the State targeted by the obligation to cooperate fully. Article 89 specifies that States obliged to cooperate fully with the Court must comply with requests for arrest and surrender - which may concern non-nationals. It is in particular though the implementation of this provision that States enforcing an ICC arrest warrant could be violating the immunities owed to another State. By ratifying the Statute, States mutually agree to this provision and are thereby lifting their international law immunities towards other States cooperating with the Court. ${ }^{177}$ By imposing an obligation to cooperate fully with the Court, the SC puts upon the targeted State all the provisions of Part 9 of the Statute, including the lifting of international law immunities from foreign criminal jurisdiction enforcing an ICC arrest warrant related to the referred situation. It is this Chapter VII obligation imposed on a non-party State - which would otherwise violate the pacta tertiis principle - that puts the targeted State in an analogous position to a State party (or more accurately to a non-party State that issued a declaration of acceptance under Article 12 (3)).

The exception to Article 89 is obviously provided in Article 98. However, the obligation to 'cooperate fully' imposed by the SC on the targeted State implies that Article 98 (1) does not prohibit the arrest of an official from this (third) State. ${ }^{178}$ Indeed, Article 98(1) allows the Court to proceed with a request for arrest and surrender of a third State's official entitled to immunity if the cooperation of the relevant third state has been obtained. The SC resolution obliging the targeted State is meant to legally ensure such cooperation. ${ }^{179}$ As

176 Reisinger Coracini, "Cooperation," 99; Prosecutor v. Al-Bashir, Case No. ICC-o2/o5-o1/o9266, Decision on the non-compliance by the Republic of Djibouti with the request for arrest and surrender Omar Al-Bashir to the Court and referring the matters to the United Nations Security Council and the Assembly of States Parties to the Rome Statute (Jul. 11, 2016), para. 10.

177 Cryer, International Criminal Law, par. 14.92.

178 Boschiero, "Judicial Finding on Non-Cooperation,", 650; De Wet, "The Implications of President Al-Bashir," 1061.

179 De Wet, "The Implications of President Al-Bashir," 1061. 
mentioned, the State targeted by the obligation to cooperate fully is theoretically accepting (and carrying out, even if it is recalcitrant) its cooperation with the Court.

Finally, the obligation to 'cooperate fully' makes clear that the Rome Statute, including Article 27(2), is imposed upon the targeted State for the purpose of enforcement as well. Indeed, the international law immunities from foreign domestic jurisdiction of the non-party State obliged to 'cooperate fully' have been lifted by the imposition of Article $27(2)$ combined with Article 89 upon that State. With regards to other non-party States that are not under the obligation to cooperate fully, Article 27 is not imposed on them at the horizontal level, and thus has no effect on their immunities from foreign domestic jurisdiction. ${ }^{180}$ While these non-party States have no obligation to arrest and surrender an official from a State obliged to cooperate fully with the Court, they are permitted to do so given that his/her immunities have been lifted. ${ }^{181}$

Overall, States requested to enforce an arrest warrant against an official from a State obliged to cooperate fully with the Court are not faced with conflicting obligations. The obligation to cooperate imposed by the SC (or by the Rome Statute) acts as a lex specialis to the general rule on immunity of State officials from foreign domestic jurisdiction. While a SC clarification on the status of the immunities of the State targeted by the obligation to cooperate is not $a$ sine qua non for finding that such immunities do not apply, it could undeniably provide an aid for the ICC to uphold its position. Nonetheless, it would certainly go against logic to presume that while referring a situation to the ICC, the SC had intended that those who bear the greatest responsibility could evade the Court's proceedings, even if their State were obliged to cooperate with the Court. If this was the intention of the SC, it should have been stated explicitly.

In any event, given the alleged ambiguity surrounding the effects of an obligation to cooperate fully with the Court upon the immunities of the targeted State's officials, the AU continues to call on its Member States not to enforce the arrest warrants against Al-Bashir. ${ }^{182}$ Member States of the AU have thus argued that the Court request for arrest and cooperation puts them in a situation where they are asked to act inconsistently with their obligations stemming from the decision of the African Union. ${ }^{183}$ Other States, claims that the Court's

\footnotetext{
180 Their officials are however subject to the ICC jurisdiction, see section 4.2 of this chapter.

181 Akande, "Impact on Al Bashir's Immunities," 348.

182 Decision on the International Criminal Court, Doc. EX.CL/1068(XxxII), Assembly/AU/ Dec.672(xxx), 3oth Ordinary Session of the Assembly, 28-29 January 2018, Addis Ababa, Ethiopia, par. 2(3).

183 E.g. see Decision on DRC Failure to Arrest Al-Bashir.
} 
request to arrest and surrender are in conflict with their obligations - not only to respect Al-Bashir' immunities to which he is entitled under customary international law but also those - enshrined in international agreements.

\subsubsection{Conflict between SC Referrals and Other Treaty Obligations}

In situations of competing treaty obligations for States that are parties to the Rome Statute and to another treaty which commands them not to comply with their obligation under the Rome Statute, a classical norm conflict appears to arise. Although the SC does not need to explicitly waive (or remove) the immunities of high-ranking officials of the targeted States as this is a necessary implication of the obligation to cooperate fully with the court, States party to the AU also find themselves under the obligation to retain the immunity of the Head of State of Sudan, as decided by AU decision. ${ }^{184}$ Let us remind ourselves that the AU has determined that "AU Member States shall not cooperate pursuant to the provisions of Article 98 of the Rome Statute of the ICC relating to immunities, for the arrest and surrender of President Omar El Bashir of The Sudan." 185 The AU had also requested its Member States not to enforce the ICC arrest warrants against Muammar Gaddafi. ${ }^{186}$

The resolutions referring Libya and Darfur, Sudan to the ICC decided that only the territorial State was to "cooperate fully with the Court". States not party to the Statute (apart from Libya and Sudan) had no obligation under the Statute. ${ }^{187}$ Thus, other States are either obliged by the Statute because of their status as States parties or, if they are not party to the Statute, simply invited to cooperate with the Court in the fulfilment of its mission. ${ }^{188}$ However, none of these obligations - except in the case of the targeted States - arise from the UN Charter.

Nevertheless, the SC could have adopted the referrals under Chapter vII of the UN Charter to impose an obligation to cooperate with the Court on all UN Member States, including States not party to the Statute. In such cases the obligation to cooperate would have stemmed directly from the UN Charter. In case of conflict with another treaty that obliges a State not to arrest and surrender

184 Constitutive Act of the African Union, Art. 23 (2); see also Assembly/AU/Dec.296(xv); The same was requested for the arrest warrant against Gaddafi, Assembly/AU/Dec.366(XvII), par. 6.

185 Assembly/AU/Dec.245(XIII) Rev.1, par. 10.

186 Assembly/AU/Dec.366(XVII), par. 6. for a comprehensive record of AU actions see Ssenyonjo, "The Rise of the African Union," 385.

187 The SC Resolutions "urge[d] all States and concerned regional and other international organizations to cooperate fully" with the Court.

188 Non-party States may decide to cooperate with the Court on an ad hoc basis, as foreseen in Article 87(5)(a) of the Statute. 
officials the obligation under the Charter would prevail, via Article 103 of the UN Charter. ${ }^{189}$

The above reasoning cannot be so easily applied to Al-Bashir since only Sudan's obligation to cooperate stems from the UN Charter. ${ }^{190}$ Nonetheless, the Pre-Trial Chamber in Decision on DRC Failure to Arrest Al-Bashir considered that since "the SC acting under Chapter VII, has implicitly lifted the immunities of Omar Al-Bashir by virtue of resolution 1593 (2005), the DRC cannot invoke any other decision, including that of the African Union, providing any obligation to the contrary."191

Akande argues that every UN Member State is bound to accept the decision of the SC to refer a situation to the ICC. ${ }^{192}$ Though the SC may choose not to oblige all UN members to cooperate fully with the Court; they remain nonetheless obliged to accept that the SC decided to apply the Rome Statute to Sudan, including Article 27 (2) ${ }^{193}$ Thus, Akande frames the referrals in terms of obligations which create the possibility of invoking Article 103 UN Charter in the case of norm conflict. ${ }^{194}$ Accordingly, UN Member States' obligation to accept that the immunities of officials from the targeted States are lifted prevails over their obligation to retain the immunities of Heads of States arising from another treaty. This seems to have been the reasoning of the Pre-Trial Chamber while issuing Decision on DRC Failure to Arrest Al-Bashir - albeit it was not phrased in clear terms.

Other States have also tried to argue that the request to arrest and surrender Al-Bashir was conflicting with other agreements to which they were party. During the proceedings relating to the Decision on South Africa Failure to Arrest Al-Bashir, South Africa argued that during his visit in June 2015, Al-Bashir benefitted from immunity from arrest on the basis of the Host Agreement concluded for the purpose of holding the AU Summit in Johannesburg. ${ }^{195}$ The argument was however rejected on the ground that Al-Bashir attended the AU Summit in his capacity as Head of State of Sudan and not as a member of the AU Commission, as a staff member of said Commission, or as a delegate

189 UN Charter, Art. 103 reads as follows: "In the event of a conflict between the obligations of the Members of the United Nations under the present Charter and their obligations under any other international agreement, their obligations under the present Charter shall prevail."

190 Du Plessis an Gevers, "Balancing Competing Obligations," 16.

191 Decision on DRC Failure to Arrest Al-Bashir, par. 31

192 Akande, "Impact on Al-Bashir's Immunities," 347-348.

193 Ibid., at $347-348$.

194 Ibid., at $347-348$.

195 Decision on South Africa Failure to Arrest Al-Bashir. 
or other representative of an inter-governmental organization, as provided by the said Host Agreement -196 a reading also retained by the Supreme Court of Appeals of South Africa. ${ }^{197}$ If, however, the hosting agreement had been found to provide immunity to Al-Bashir, the obligation to arrest Al-Bashir stemming from SC resolution 1593 would have, in accordance with Article 103 of the UN Charter, taken precedence over the said international agreement.

Finally, in the proceedings concerning the Decision on Jordan Failure to Arrest Al-Bashir, it has been argued that Al-Bashir was protected by the 1953 Convention on the Privileges of the Arab League, and that such 'international agreement' should be read in the light of Article 98(2) Rome Statute. Article 98(2) of the Rome Statute reads as follows:

The Court may not proceed with a request for surrender which would require the requested State to act inconsistently with its obligations under international agreements pursuant to which the consent of a sending State is required to surrender a person of that State to the Court, unless the Court can first obtain the cooperation of the sending State for the giving of consent for the surrender.

The Pre-Trial Chamber II responded that this provision does not apply to the 1953 Convention given that the latter "does not refer to a 'sending State' and does not establish or refer to a procedure for seeking and providing consent to surrender."198 Article 98(2) has indeed been conceived as applying to scenarios in which the Court seeks the arrest and surrender of personnel specifically "sent" to the territory of a State Party pursuant to an agreement concerning their status on that territory, such as a Status of Forces Agreement. ${ }^{199}$ In any event, the effect of SC resolution would once again prevail over such international agreements if they were found to exist with regards to a suspect in a situation referred to the Court by the SC.

To sum up, when a treaty conflicts with a UN Charter obligation, including obligations arising from a SC resolution under Chapter VII, the former is set aside to the extent of its inconsistency with the latter. The State facing such a

196 Decision on South Africa Failure to Arrest Al-Bashir, par. 67.

197 Minister of Justice and Constitutional Development and Others v Southern African Litigation Centre and Others (867/15) [2016] ZASCA 17; 2016 (4) BCLR 487 (SCA); [2016] 2 All SA 365 (SCA); 2016 (3) SA 317 (SCA) (15 March 2016), par. 40-48.

198 Prosecutor v Al-Bashir, ICC-O2/o5-o1/og, Decision under article 87(7) of the Rome Statute on the non-compliance by Jordan with the request by the Court for the arrest and surrender or Omar Al-Bashir (Dec. 11, 2017), par. 32.

199 Prost, "The Surprises," 3-4. 
norm conflict "is merely prohibited from fulfilling an obligation arising under that other norm."200 Thus, the conflict is resolved without any wrongfulness due to the breach of the conflicting norm. ${ }^{201}$

\subsection{Universal Jurisdiction Conception}

The 'universal jurisdiction conception' of a referral under Article 13 (b) is that this mechanism triggers the jus puniendi of the international community. According to this view, the Rome Statute was designed by the international community as a codification of the most serious crimes of concern which must not go unpunished. Although the international community assumed a legislative role and entrusted the Court with the right to adjudicate the crimes it prescribed, it left jurisdiction to enforce to States. Thus, States, when enforcing an ICC arrest warrant, simply act as the 'artificial limbs' of the Court.

Although the arrest and surrender of a suspect have to be operated by national authorities, this exercise of jurisdiction to enforce is done on behalf of the jus puniendi entrusted to the ICC. ${ }^{202}$ Formally, it can be argued that, jurisdiction to adjudicate the crimes committed by the high-ranking State official is not exercised by national authorities. This does not mean that the immunity and inviolability of a high-ranking State official is not a bar to such an act of State. ${ }^{203}$ However, States enforcing an ICC arrest warrant are not acting contrary to par in parem imperium non habet. It is the ICC - an international criminal jurisdiction representing the "collective will" - that adjudicates the conduct of the high-ranking State official. States, in other words, provide what is lacking to the ICC: a police force that can arrest and surrender the suspected criminals the Court seeks. The Pre-Trial Chamber in Decision on the Failure of Malawi to Arrest and Surrender Al-Bashir has indeed declared that

when cooperating with this Court and therefore acting on its behalf, States Parties are instruments for the enforcement of the jus puniendi of the international community whose exercise has been entrusted to

\footnotetext{
200 See Report of the Study Group of the ILC on Fragmentation of International Law, par. 334

201 See Draft Articles on Responsibility of States for Internationally Wrongful Acts, Art. 59; However, see Report of the Study Group of the ILC on Fragmentation of International Law par. 343; see also Du Plessis and Gevers, "Balancing Competing Obligations," 4-5.

202 Kress, "Immunities under International Law," 257.

203 The ICJ in Certain Questions of Mutual Assistance in Criminal Matters (Djibouti vs France), ICJ Reports 2008, par. 170, held: "the determining factor in assessing whether or not there has been an attack on the immunity of the head of State lies in the in the subjection of the latter to a constraining act of authority."
} 
this Court when States have failed to prosecute those responsible for the crimes within this jurisdiction. ${ }^{204}$

Under the same assumption as to proceedings before the ICC, it can be contended that immunities of State officials under international law do not apply when a State is enforcing an arrest warrant issued by the ICc. The customary exception to the rule on immunity for certain international criminal courts is extended to the enforcement apparatus of the institution entrusted with the jus puniendi of the international community. Accordingly, the States party to the Rome Statute's acts of arrest and surrender is "part of a vertical cooperation regime which in turn constitutes the external part of those international proceedings."205

In terms of norm conflict we are beyond a simple accumulation of norms. While the ICJ did state that immunities are no bar to prosecution when "certain international criminal courts" exercise jurisdiction, it did not explicitly extend this exception to States executing an arrest warrant from these courts. The solution to the apparent conflict is however provided by effective interpretation of the alleged customary international law exception - codified in Article 27 (2) - to immunities under international law for proceedings related to an international criminal jurisdiction. If we consider that customary international law provides an exception to immunity for international criminal proceedings, the principle of effectiveness warrants that this exception to immunity extends to States' measures of arrest and surrender to the international criminal courts. Such a construction renders the application of Article 27 (2) fully operational. Indeed, no immunities could be raised when the ICC seeks through its 'artificial limbs' to exercise jurisdiction; this would apply equally to all, including high-ranking officials of a State not party to the Rome Statute.

However, this interpretation is even more contested than the 'universal jurisdiction conception' view on the irrelevance of immunity of heads of States from the ICC. In particular, it has been contended that to extend Article 27 (2) to immunities of third States from arrest and surrender by foreign national authorities would deprive Article 98 of its content. ${ }^{206}$ One of the rules when using effective interpretation is that it should not render another norm meaningless. ${ }^{207}$ Kress, who participated in the drafting of the provision, enlightens

\footnotetext{
204 Decision on Malawi Failure to Arrest Al-Bashir, par. 46.

205 Kress and Prost, "Article 98," 1613.

206 VCLT, Article 31; see Tladi, "The ICC Decisions on Chad and Malawi," 207-209; Iverson, "The Continuing Functions," 140-141.

207 Pauwelyn, Conflict of Norms, 250.
} 
the discussion by informing us that at the Rome Conference no decision could be reached on the immunity of State officials from national courts enforcing an arrest warrant. ${ }^{208}$ Thus, the drafters left the issue to be decided by the Court. Arguably, the relevance of Article 98 with regard to immunity from arrest and surrender to the ICC could have become obsolete. Those supporting such view can rely on the fact that the Statute has been ratified by an ample majority of States and several national legislations implementing the Statute do not distinguish between immunities of officials of States parties and non-party States. ${ }^{209}$ Moreover, it can be claimed that Article $98(1)$ is not rendered completely inapplicable. In addition to the immunity from criminal jurisdiction of State officials of third States, Article 98 (1) is also directed at the inviolability of diplomatic premises, as contained in Article 22 of the Vienna Convention on Diplomatic Relations. ${ }^{210}$ Finally, Article 98 (2) remains relevant for 'host State agreements' and 'status of forces agreements'.211 Thus, it may be argued that Article 98 Rome Statute is not fully deprived of its content.

Despite the availability of these interpretative tools to avoid a genuine conflict with the immunity of State officials from foreign domestic criminal proceedings, we have seen that the customary exception for certain international criminal courts is far from established. To extend this exception to States enforcing an ICC arrest warrant is even more difficult to defend. Many States, including States party to the Rome Statute, disagree with the ICC on the content of Article 98(1) and the scope of immunity ratione personae under customary international law. Furthermore, it must be acknowledged that Article 98 (1) tacitly recognizes that the ICC might first need to seek a waiver before issuing a request for arrest and surrender of an official entitled to immunities under international law. ${ }^{212}$ From the serious challenges AU States have posed to

208 Kress, "Immunities under International Law," 232.

209 See e.g. the Mauritius International Criminal Court Act of 2011 (in particular section 14), the Kenya International Crimes Act of 2004 (in particular section 62), the Trinidad and Tobago International Criminal Act of 2006 (in particular section 66); see also the South African Implementation of the Rome Statute Act of 2002. See also Tladi, "The ICC Decisions on Chad and Malawi," 211; contra Daqun, "Non-Immunity for Heads of State," 67.

210 See also Kress, "Immunities under International Law," 232-233, 236-239; Kress and Prost, "Article 98," 1607, both delegates at the Rome Conference writes that "it was the inviolability of diplomatic premises that was at the heart of the debate on Article 98 para. 1"; See also Iverson, "The Continuing Functions," 140-141.

211 Rome Statute, Art. 98(2) reads: "The Court may not proceed with a request for surrender which would require the requested State to act inconsistently with its obligations under international agreements pursuant to which the consent of a sending State is required to surrender a person of that State to the Court, unless the Court can first obtain the cooperation of the sending State for the giving of consent for the surrender."

212 Daqun, "Non-Immunity for Heads of State," 66. 
the ICC, it was indeed advisable for the Court to reconsider whether its States parties have a legal obligation under international law with respect to the immunity of high-ranking officials of States not party to the Rome Statute. ${ }^{213}$ The repetitive change of mind of the ICC Pre-Trial Chamber II on the relationship between Article 27(2) and 98(1) demonstrate that the Court has slowly recognized that heads of States not party to the Rome Statute are entitled to immunity from arrest and surrender by a foreign State.

Furthermore, even some of the scholars that consider that Article 27(2) reflects customary international law, believe that officials entitled to immunity ratione personae cannot be the object of a request for arrest and surrender, if no waiver is issued by the relevant authorities. In particular, Gaeta and Labuda argue that by having asked its States parties to arrest and surrender Al-Bashir, the ICC is requesting its States parties to commit internationally wrongful acts, and is therefore breaching Article 98(1) of the Rome Statute. ${ }^{214}$ In their view, "[a]ffording protection from arrest in foreign countries to a narrow group of officials from States not parties to the Rome Statute, such as Sudan, may shield a few individuals from prosecution in the short term, but this may well be the price to pay for ensuring that other important aspects of the international system remain intact."215 Certainly, the 'universal jurisdiction conception' would be less under tension if it did not purport to also overwrite the customary immunity of heads of States from foreign domestic jurisdiction.

It may moreover be asked whether the legal tools at the disposal of the 'universal jurisdiction conception' to resolve a conflict with a contradicting obligation arising from another treaty do not risk delegitimizing the whole project. In situations where a State party is requested by the ICc to enforce an arrest warrant and is also obliged under another treaty not to comply with the ICC's requests, the State party appears to be put in a norm conflict situation. As pointed out above, such a scenario occurred in the Al-Bashir Case. ${ }^{216}$ In Decision on the Failure of Malawi to Arrest and Surrender Al-Bashir, Pre-Trial Chamber I considered that since it was established under customary international law that no immunity existed for proceedings related to an arrest warrant by the ICC, "[ $t]$ here is no conflict between Malawi's obligations towards the Court and its obligation under customary international law; therefore, Article 98(1) of the Statute does not apply"217 Simply, the Pre-Trial Chamber considered that

\footnotetext{
213 Boschiero, "Judicial Finding on Non-Cooperation," 638-639.

214 Gaeta and Labuda, "Trying Sitting Heads of State," 149-151.

215 Ibid., at 157.

216 See Ssenyonjo, "The Rise of the African Union," 385.

217 Decision on Malawi Failure to Arrest Al-Bashir, par. 43.
} 
the AU obligation was invalid - as it (in the opinion of the ICC) incorrectly held that immunity existed under customary international law - and thus did not fit within the situations foreseen in Article 98 (1).218

Although the ICC offered to Malawi to avoid the norm conflict it was facing by considering that $\mathrm{AU}$ obligation not to arrest and surrender Al-Bashir did not have any legal force, Malawi is still in an unresolvable norm conflict. Either it decides to follow the ICC's requests and breach its obligation towards the AU (with the counter-argument that the AU resolutions are invalid) or it decides to abide by the AU resolution (with the counter-argument of Article 98 (1)) and breach its obligation to arrest and surrender to the ICC. Since none of these obligations is hierarchically superior to the other there is no easy way out to this norm conflict. Such unresolvable conflict might be one of the reasons the AU call for a mass withdrawal of its Member States from the ICC.

\section{Conclusion}

In 2014, the Prosecutor of the ICC announced that she will 'hibernate' investigative activities in Darfur. ${ }^{219}$ This decision was admittedly taken because the Prosecutor faced a lack of cooperation from the government of Sudan but also from all other States, including State parties. ${ }^{220}$ The Prosecutor also addressed the SC, blaming it for its absence of responses to the numerous calls to take actions in order to ensure States' compliance with the Court requests for cooperation. ${ }^{221}$ This decision arose in the context of an unsucessful call by the then Argentinian Presidency of the SC to establish an effective follow-up mechanism for the SC referrals to the Court. ${ }^{222}$ During this series of meetings the Russian representative said:

218 Decision on Malawi Failure to Arrest Al-Bashir, par. 37; see Kiyani, "Al-Bashir \& the ICC," 506.

219 Office of the Prosecutor, Statement to the United Nations Security Council on the Situation in Darfur, pursuant to SC Resolution 1593 (2005) (Dec. 12, 2014).

220 Office of the Prosecutor, Twentieth Report of the Prosecutor of the International Criminal Court to the UN Security Council pursuant to the SC Resolution 1593 (2005) (Dec. $15,2014)$.

221 Office of the Prosecutor, Statement to the United Nations Security Council on the Situation in Darfur, pursuant to SC Resolution 1593 (2005) (Dec. 12, 2014).

222 Letter dated 8 October 2014 from the Permanent Representative of Argentina to the United Nations addressed to the Secretary-General; See also Security Council, 7285 th meeting, UN Doc. S/PV.7285, S/PV.7285 (Resumption 1) (Oct. 23, 2014). 
In our view, the reasons for States' lack of willingness to cooperate with the ICC to a large extent lie within the Rome Statute itself, as well as with the Court's accumulated practice, including on bringing to justice senior public officials of States. For example the Court's interpretation of the immunity of these individuals has been somewhat ambiguous. ${ }^{223}$

Clearly, the Russian representative was pointing to the various AU resolutions not to cooperate with the Court in response to the Decision on the Failure of Malawi to Arrest Al-Bashir. ${ }^{224}$ This lack of cooperation with the arrest warrant of Al-Bashir shows that the international community, including States party to the Rome Statute, disagrees with the ICC's interpretation of its Statute.

The reaction of inter alia the AU to Decision on Malawi Failure to Arrest AlBashir has prompted the Court to change its reasoning with respect to the effect of Article 27 Rome Statute towards non-party States. Thus, in Decision on DRC Failure to Arrest Al-Bashir Pre-Trial Chamber II took a more considered approach by putting the emphasis on the effect of Article 25 and 103 of the UN Charter. The waiver theory was however still challenged. The Pre-Trial Chamber thus adopted a new reasoning in Decision on South Africa Failure to Arrest Al-Bashir. These changes of mind might be said to prove that the ICC has understood that the 'universal jurisdiction conception' undermines its objective of universality. Indeed, the two last decisions put the emphasis on the fact that the Rome Statute is first and foremost a multilateral treaty that cannot impose obligations on third States without their consent - only the SC can impose such obligations.

While Jordan has brought the reasoning exposed in Decision on South Africa Failure to Arrest Al Bashir to the Appeals Chamber, it is the opinion of this author that the object and purpose of a SC referral, accompanied with a Chapter VII obligation to cooperate fully with the Court, cannot but mean that the immunities of the targeted State's officials are inapplicable before the Court as well as before States enforcing an ICC arrest warrant issued in the referred situation. Other non-party States' officials are, according to the view developed above, not immune from the Court's jurisdiction in the situation referred by the SC. But given that they have no obligation to cooperate with the Court they have no obligation to surrender their officials, which also remain immune from foreign domestic jurisdiction. According to this author, such distinction reflects the difference between the SC decision to refer a situation to the ICC, which must be accepted by all UN Members States, and the obligation to cooperate with the Court imposed on specific States.

223 See also Security Council, 7285 th meeting, UN Doc. S/PV.7285 (Oct. 23, 2014).

224 African Union Commission, Press Release No 002/2012, (Jan. 9, 2012). 
There are great chances that if the AU is not satisfied with the Appeals Chamber judgment, the issue might end up at the ICJ. Indeed, at the 18th Ordinary Session of the Assembly of the AU, the AU Commission was requested to "consider seeking an advisory opinion from the International Court of Justice regarding the immunities of State officials under international law." 225 After several years, the AU decided in 2018 to request the African Group in New York to lobby the UN General Assembly to seek an advisory opinion from the ICJ on the "question of immunities of a Head of State and Government and other Senior Officials as it relates to the relationship between Articles 27 and 98 and the obligations of States Parties under International Law". 226 This request clearly expresses the belief that clarification is needed with regard to the applicability of Article 27(2) to States not party to the Rome Statute.

It must also be noted that the SC clearly failed to assume the responsibilities attached to its referrals. The ICC, acting under Article 87 (7) of the Rome Statute, referred to the SC seven instances where a State party had failed to arrest and surrender Al-Bashir. These referrals were not followed up by the SC. The same inertia prevailed when Sudan or Libya were referred back to the SC for failing to arrest and surrender nationals under a warrant for arrest. The SC will not clarify whether it intended to remove the immunities of State officials when triggering the Court's jurisdiction. But nothing in the text and context of the SC referrals evinces an attempt to exclude Article 27 for the nationals of the targeted States - while both SC referring resolutions address explicitly the immunities of officials of non-party States (other than Sudan or Libya). ${ }^{227}$

It has been shown in the preceding chapters that the 'universal jurisdiction conception' can put forward plenty of legal arguments to avoid most of the normative conflicts arising from an exercise of jurisdiction over nationals and territories neither party to the Statute nor consenting to the ICC's jurisdiction.

225 Decision on the Progress Report of the Commission on the Implementation of the Assembly Decisions on the ICC, Doc, EX. EX.CL/710 (xx), Assembly/AU/Dec.397, XVIII, 29-30 January 2012, par. 10; the AU does not have the capacity to request Advisory Opinion to the ICJ, under Art. 96 of the UN Charter and Art. 65 of the Statute of the ICJ, only organs of the United Nations or UN specialized agencies may be authorised by the UN General Assembly to request advisory opinions.

226 Decision on the International Criminal Court, Doc. EX.CL/1068(xxxII)3oth Ordinary Session of the Assembly, 28-29 January 2018, Addis Ababa, Ethiopia, Assembly/AU/ Dec.672(Xxx), par. 5(II).

227 Whether the peacekeepers exemption paragraphs bind the Court is addressed in Chapter 4 . 
However, despite the principled approach of treating cases alike, the legal tools available to the 'universal jurisdiction conception' seem to be on the edge of the international legal system as it currently stands. Even if the 'fight against impunity' is one of the overarching raisons d'être of the ICC, over-stretching legal reasoning to attain this goal risks provoking strong contestation that might wreck the whole ICC project.

One of the goals of the ICC is to support international criminal law, including compliance with its norms. ${ }^{228}$ Lack of cooperation is undoubtedly one of the most serious challenges the Court is facing. The refusal to cooperate with the Court obviously affects its effectiveness. ${ }^{229}$ Ending impunity and strengthening deterrence against the commission of international crimes can only be achieved if international criminal law and the institutions that have been established to enforce it are seen as legitimate. Thus, the ICC must take an interpretative approach to the norms contained within its Statute that convinces States that it is in accordance with international law.

States that have ratified the Rome Statute may 'contract out' inter se of certain norms of international law. For instance, the crimes defined within the Rome Statute are 'for the purpose of this Statute'. The law of the Statute thus becomes the lex specialis the Court is supposed to apply. However, in their treaty relations States "cannot contract out of the system of international law."230 Only the SC can, with few exceptions. The Rome Statute's sweeping application and interpretation as being applicable to all because its States parties allegedly decided so has been decried as not being in accordance with the 'right process'. Hence, the refusal of its State parties to comply with the Court's requests to arrest and surrender Al-Bashir. Legitimacy exerts a pull towards compliance and in turn provides legitimacy to international courts. ${ }^{231}$ For these reasons the 'universal jurisdiction conception' should not be used to explain what an Article 13 (b) referral is, what its effects are and what it should be.

This is not to say that the 'Chapter VII conception' does not face other legitimacy problems. However, the legal authority of the SC to refer a situation to the ICC seems to be an issue that is no longer open to contestation. While it has been claimed that the SC should be more explicit in its referrals about the immunity of heads of States, the power to remove such immunities appears

228 Shany, Effectiveness, 227.

229 Ibid., p. 141.

230 Pauwelyn, Conflict of Norms, 37.

231 Shany, Effectiveness, $155^{-157 .}$ 
to be included in the wide array of measures it can take under Article $41 \mathrm{UN}$ Charter. The 'Chapter vil conception' has thus proved to offer ways of avoiding and resolving norm conflicts that are in accordance with contemporary international law. The reach of that 'conception' might seem limitless. In the next chapter, we will address where the Chapter viI powers end when the SC refers a situation to the ICC. To properly understand the relationship between the SC and ICC it is enlightening to ask ourselves: what if Articleıs (b) did not exist? 